\title{
ILLINOIS STATE GEOLOGICAL SURVEY RADIOCARBON DATES VII
}

\section{CHAO LI LIU and DENNIS D COLEMAN}

\section{Illinois State Geological Survey, Champaign, Illinois 61820}

The following list contains samples of geologic interest that were processed from February 1974 through May 1980 at the Illinois State Geological Survey (ISGS) Radiocarbon Dating Laboratory. The archaeologic samples processed during the same period will be published in our next date list. The benzene liquid scintillation technique was used following laboratory procedures previously reported by Coleman (1973; 1974).

All ages were calculated on the basis of a ${ }^{14} \mathrm{C}$ half-life of $5568 \mathrm{yr}$, using the NBS oxalic acid standard as reference. Errors $(1 \sigma)$ reported account only for uncertainties in activity measurements of the sample, standard, and backgrounds. All age calculations have been computerized with the assignment of modern and minimum ages based on the $4 \sigma$ criteria as previously reported (Coleman, 1973). Activities of "modern" samples are given as \% of modern. Corrections for isotopic fractionation have been included for samples dated since December 1979.

\section{SAMPLE DESCRIPTIONS}

\section{A. Lake Michigan shoreland}

Samples are from SE Wisconsin and NE Illinois. Unless otherwise noted samples were coll 1974 by C E Larsen; subm by C E Larsen and Charles Collinson, ISGS.

\section{North Shore Channel, Chicago River series}

Site in Cook Co, Chicago, Illinois (41 $\left.58^{\prime} 29^{\prime \prime} \mathrm{N}, 87^{\circ} 42^{\prime} 15^{\prime \prime} \mathrm{W}\right)$.

ISGS-266.

$4300 \pm 80$

Unios shell from gravelly sand near base of sand-silt sequence. Coll 1914 by F C Baker. Comment (CEL): presence of Elliptio crassidens in faunal assemblage from which sample was taken indicates water depth of at least $1.8 \mathrm{~m}$ at time of deposition. Date marks peak of Lake Nippissing stage of Great Lakes, which attained at least $183 \mathrm{~m}$ elev based on faunal assemblage.

ISGS-286.

$4190 \pm 80$

Peat from unit $12 \mathrm{~cm}$ thick, $2 \mathrm{~m}$ above water level. Comment (CEL): peat deposit was formed on marsh silts and clays overlying faunal assemblage assoc with Lake Nippissing stage and dated by ISGS-266. Date marks relatively rapid drop in lake level below $179 \mathrm{~m}$ prior to $4190 \pm 80$ BP. Date is significant in that it shows rapid termination of Lake Nippissing, and drop in lake level below Lake Algoma stand at 180 to $181 \mathrm{~m}$.

ISGS-356. Bull Creek

$1750 \pm 80$

Organic silt from Lake Co, $1.8 \mathrm{~km} \mathrm{~S}$ of Central School, Zion, Illinois $\left(42^{\circ} 25^{\prime} 51^{\prime \prime} \mathrm{N}, 87^{\circ} 50^{\prime} 10^{\prime \prime} \mathrm{W}\right)$. From organic silt zone, $15 \mathrm{~cm}$ thick, $1 \mathrm{~m}$ 
below top of bank. Comment (CEL): dates paleosol that marks period of nondesposition during formation of $2 \mathrm{~m}$ alluvial terrace along Bull Creek. Alluviation may be due to fluctuations in runoff, or changes in lake level.

\section{Kellogg Creek series}

Site in Lake Co, $1.3 \mathrm{~km} \mathrm{~S}$ of Winthrop Harbor, Illinois $\left(42^{\circ} 28^{\prime} 04^{\prime \prime}\right.$ $\left.\mathrm{N}, 87^{\circ} 49^{\prime} 25^{\prime \prime} \mathrm{W}\right)$.

ISGS-278.

$$
1580 \pm 80
$$

Wood from base of terrace. Comment (CEL): date provides limit for $2.4 \mathrm{~m}$ sedimentation along Kellogg Creek. Alluvial fill is thought to relate to series of fluctuations higher than present lake levels between $1750 \pm 80$ BP, (ISGS-356) and present.

ISGS-279.

Organic silt from $0.5 \mathrm{~m}$ below top of dissected terrace. Comment (CEL): dates soil development during upward growth of alluvial fill. Organic zone may be related to Late Woodland archaeol site later covered by further sedimentation. Alluvial fill is thought related to higher than present lake level between $1165 \pm 75$ BP, (ISGS-169) and $715 \pm 75$ вP, (ISGS-186; R, 1975, v 17, p 161).

\section{ISGS-284.}

$$
1110 \pm 80
$$

ISGS-285.

$$
1200 \pm 80
$$

From organic silt layer exposed in creek bank, 1.2 to $1.3 \mathrm{~m}$ above water level. Comment (CEL): samples from black silt unit that defines W margin of buried marsh. Marsh now covered by $74 \mathrm{~cm}$ layered fine sands and sandy silts of probable alluvial origin from Kellogg Creek. Dates provide limit for onset of alluviation in this portion of creek.

ISGS-351.

Wood from silty sand near water level $1.75 \mathrm{~m}$ below top of bank. Comment (CEL): date indicates that $2 \mathrm{~m}$ terrace at this site is recent landform caused by increased sedimentation and changes in runoff, or more likely, fluctuation in Lake Michigan water level.

\section{Fossland Park, Winthrop Harbor series}

Organic silt from Lake Co, $0.6 \mathrm{~km}$ NE of Winthrop Harbor, Illinois $\left(42^{\circ} 29^{\prime} 08^{\prime \prime} \mathrm{N}, 87^{\circ} 49^{\prime} 20^{\prime \prime} \mathrm{W}\right)$.

ISGS-333.

$$
1320 \pm 80
$$

Organic silt from unit, $5 \mathrm{~cm}$ thick, $105 \mathrm{~cm}$ below top of terrace. Comment (CC): dates paleosol that probably represents period of base level stabilization.

ISGS-350.

$$
1020 \pm 80
$$

Organic silt from paleosol, $5 \mathrm{~cm}$ thick, $45 \mathrm{~cm}$ below top of terrace. Comment (CEL): paleosol marks period of nondeposition during formation of terrace $2 \mathrm{~m}$ high along small stream; $50 \mathrm{~cm}$ silty, fine sand depos- 
ited on unit due to fluctuation in runoff or changes in level of Lake Michigan.

ISGS-367.

Wood from clayey-silty sand just above water level, ca $100 \mathrm{~cm}$ below top of stream bank. Comment (CC): sample may have been contaminated by plant rootlets. Date, $>4300$ BP, was expected based on nearby dates of related features.

\section{Carol Beach series}

Organic sandy silt from Kenosha Co, $3.2 \mathrm{~km}$ SSE of S Kenosha, Wisconsin $\left(42^{\circ} 30^{\prime} 30^{\prime \prime} \mathrm{N}, 87^{\circ} 48^{\prime} 30^{\prime \prime} \mathrm{W}\right)$, from Grayslake Peat.

ISGS-253. 55 to $64 \mathrm{~cm}$ depth

$\mathbf{7 7 0} \pm \mathbf{8 0}$

From base of gray sandy silt unit underlain by black silty sand, $51 \mathrm{~cm}$ thick.

ISGS-265. 95 to $110 \mathrm{~cm}$ depth

$3280 \pm 80$

From base of black silty sand.

General Comment (CEL): date is min for beach sands on which organic deposits were developed.

\section{Barnes Creek series}

Site in Kenosha Co, $3.3 \mathrm{~km} \mathrm{~S}$ of Kenosha, Wisconsin $\left(42^{\circ} 31^{\prime} 52^{\prime \prime} \mathrm{N}\right.$, $\left.87^{\circ} 49^{\prime} 00^{\prime \prime} \mathrm{W}\right)$.

\section{ISGS-259. 170 to $175 \mathrm{~cm}$ depth}

ISGS-260. 210 to $215 \mathrm{~cm}$ depth

$4890 \pm 80$

Wood fragments in silt from zones containing branches and roots.

General Comment (CEL): dates show upward growth of marsh sediments in relation to rising level of Lake Michigan. Nearshore sands assoc with Lake Nippissing stage of Great Lakes overlie these marsh deposits.

ISGS-263.

$560 \pm 80$

Organic sand from paleosol at depth 65 to $90 \mathrm{~cm}$. Comment (CC): paleosol developed on nearshore sand, buried by eolian sand which overlies deposits presumably from Lake Nippissing stage.

ISGS-288.

$3950 \pm 120$

Organic sand from unit, $26 \mathrm{~cm}$ thick, $1 \mathrm{~m}$ above water level. Comment (CEL): black organic sand is found directly overlying erosion surface on clayey till or compact lacustrine clayey silt. Erosion surface probably indicates incision of Barnes Creek, whereas organic sand may show ponding and marsh formation. Ponding may have resulted from temporary obstruction by formation of beach features such as dunes, or from base level change influenced by rise in level of Lake Michigan. Date may indicate lake level no higher than $179 \mathrm{~m}$ elev.

ISGS-289.

$\mathbf{5 0 0} \pm \mathbf{8 0}$

Organic sand from unit, $5 \mathrm{~cm}$ thick, $225 \mathrm{~cm}$ above water level. Comment (CEL): sample from organic sand at elev $180.5 \mathrm{~m}$. Organic sand 
and underlying nearshore sand have been exposed by lateral erosion and incision of Barnes Creek, at elev $178 \mathrm{~m}$ at this site. Organic sand may represent higher water table than at present, which gave rise to isolated pockets of vegetation and soil formation in low places. Date agrees well with ISGS-263: $560 \pm 80 \mathrm{BP}, 11 \mathrm{~m} \mathrm{~S}$ of this exposure.

ISGS-297.

$1450 \pm 80$

Organic silt from peat, $76 \mathrm{~cm}$ thick, filling abandoned channel incised into nearshore and beach sands at surface elev $180.5 \mathrm{~m}$. Comment (CEL): date limits time of abandonment of channel, and may indicate ponding in channel caused by fluctuation in level of Lake Michigan.

ISGS-313.

$5500 \pm 80$

Wood from gray gravelly sand, 270 to $275 \mathrm{~cm}$ below top of bank. Comment (CEL): date marks active stream flow prior to deposition of $1.5 \mathrm{~m}$ marsh sediments. Also conceivably marks period of lake level similar to or below present level when incision into underlying Pleistocene sediments was occurring.

ISGS-318.

$\mathbf{3 8 0 0} \pm \mathbf{8 0}$

Organic sand from dark brown unit (paleosol), ca $30 \mathrm{~cm}$ below present A horizon. Comment (CC): dates discontinuous organic layer in upper portion of nearshore sand body that limits upper date on lake transgression at ca $3800 \mathrm{BP}$.

ISGS-325.

$880 \pm 80$

Organic sand from unit $15 \mathrm{~cm}$ below top of bank. Comment (CEL): date represents mean residence time for organic soil horizon. Sample overlies ISGS-318.

ISGS-332. Tobin Road Crossing

$580 \pm 80$

Organic sand from Kenosha Co, Wisconsin, $1.8 \mathrm{~km}$ E of Tobin, Wisconsin $\left(42^{\circ} 30^{\prime} 24^{\prime \prime} \mathrm{N}, 87^{\circ} 49^{\prime} 05^{\prime \prime} \mathrm{W}\right)$. From black organic sand, $40 \mathrm{~cm}$ below top of terrace.

\section{B. Illinois}

\section{ISGS-241. Drainage Ditch Section}

Wood from Vermilion Co, $3.2 \mathrm{~km}$ W of Danville $\left(40^{\circ} 08^{\prime} 29^{\prime \prime} \mathrm{N}, 87^{\circ}\right.$ $\left.40^{\prime} 42^{\prime \prime} \mathrm{W}\right)$. From questionable early Wisconsinan or Illinoian till. Coll 1954 by G E Ekblaw and H B Willman; subm by H B Willman, ISGS. Comment (HBW): wood coll from "Farmdale till" of early Wisconsinan age by Ekblaw and Willman (1955). Date does not disprove this but later correlations of till with other exposures favor interpretation of till as Illinoian (Johnson et al, 1972).

\section{Higginsville Section series}

Sec in Vermilion Co, $1.6 \mathrm{~km}$ NW of Higginsville $\left(40^{\circ} 14^{\prime} 45^{\prime \prime} \mathrm{N}, 87^{\circ}\right.$ $\left.46^{\prime} 30^{\prime \prime} \mathrm{W}\right)$. Samples from unnamed silt occurring between Radnor and Glenburn Till Members. 
ISGS-242A. Split 1

ISGS-242B. Split 2

Organic silt. Coll 1973 and subm by D D Coleman.

ISGS-430.

Wood from organic silt. Coll 1976 and subm by W H Johnson, Univ of Illinois.

General Comment (WHJ): dates confirm that silt is not Robein Silt; it is either of early Altonian or Sangamonian age. Bald cypress wood fragments in deposit are more suggestive of Sangamonian climate, but earlier date, 48,100 \pm 1700 BP, (ISGS-63; R, 1973, v 15, p 79) suggested Altonian age.

\section{Pontiac Stone Quarry series}

Site in Iroquois Co, $11.8 \mathrm{~km}$ WNW of Ashkum $\left(40^{\circ} 54^{\prime} 11^{\prime \prime} \mathrm{N}, 88^{\circ}\right.$ $\left.05^{\prime} 08^{\prime \prime} \mathrm{W}\right)$. Coll 1974 and subm by D W Moore, Univ Illinois.

ISGS-254.

Organic material in $<2 \mu$ clay fraction of till from Chatsworth Drift, 0.7 to $0.8 \mathrm{~m}$ above bedrock.

\section{ISGS-255.}

Organic material in $<2 \mu$ clay fraction of lacustrine clay from Carmi Member of Equality Formation overlying till dated by ISGS-254.

General Comment (DWM): based on stratigraphy and other reliable Woodfordian dates, the two dates obtained from these samples do not approximate true age of sampled stratigraphic units. Dates probably resulted from overwhelming predominance of "dead" organic carbon derived from Paleozoic shales and dolomite that comprise local bedrock.

Organic silt from Henderson Co, $2.8 \mathrm{~km} \mathrm{NE}$ of Lomax $\left(40^{\circ} 41^{\prime} 32^{\prime \prime}\right.$ $\left.\mathrm{N}, 91^{\circ} 02^{\prime} 30^{\prime \prime} \mathrm{W}\right)$. From organic silt unit above thick gleyed silt that overlies Illinoian till. Coll 1972 by A B Leonard, H B Willman, and J C Frye; subm by J C Frye, ISGS. Comment (HBW): dates beginning of Wisconsinan sedimentation at this site and indicates snail faunas from overlying silt are Wisconsinan rather than Yarmouthian as previously described.

\section{ISGS-277. Cache River-Heron Pond}

$910 \pm 80$

Wood from Johnson Co, $2.2 \mathrm{~km} \mathrm{SW}$ of Forman, $\left(37^{\circ} 20^{\prime} 05^{\prime \prime} \mathrm{N}, 88^{\circ}\right.$ $55^{\prime} 14^{\prime \prime} \mathrm{W}$ ). From organic debris underlying terrace on E Bank of Cache R, $0.7 \mathrm{~m}$ below terrace surface. Coll 1974 by L R Follmer and P B DuMontelle; subm by L R Follmer, ISGS. Comment (L.RF): date indicates that erosion surface on weathered alluvium $1.5 \mathrm{~m}$ above present Cache $\mathrm{R}$ was active ca $900 \mathrm{yr}$ BP. Aggradation with organic debris and silt commenced at about this time and continued up to present. Construction of Post Creek Cutoff ca AD 1910 apparently initiated present down-cutting in upper Cache R Basin. 
Sandy peat from Kankakee Co, $12 \mathrm{~km} \mathrm{E} \mathrm{of} \mathrm{St} \mathrm{Anne}\left(41^{\circ} 01^{\prime} 22^{\prime \prime} \mathrm{N}\right.$, $\left.87^{\circ} 35^{\prime} 08^{\prime \prime} \mathrm{W}\right)$. From sandy peat unit 10 to $15 \mathrm{~cm}$ thick and $13.7 \mathrm{~m}$ below crest of dune. Coll 1974 and subm by J M Masters, ISGS. Comment (JMM): first date on period of sand dune formation (Parkland Sand) related to Lake Wauponsee area of Kankakee Flood during Woodfordian Substage. At this location, underlying main sand body was probably deposited under fluviatile-lacustrine conditions (Equality Formation), and at certain periods, sand from marginal bars and beach ridges was blown by prevailing winds eastward over adjacent peat (Grayslake Peat) that was accumulating on main sand body.

\section{ISGS-331. Clores Bridge Section}

$15,330 \pm 170$

Wood fragments from Randolph Co, $4 \mathrm{~km} \mathrm{E}$ of Chester $\left(37^{\circ} 53^{\prime} 50^{\prime \prime}\right.$ $\mathrm{N}, 89^{\circ} 45^{\prime} 37^{\prime \prime} \mathrm{W}$ ). From woody zone, $2 \mathrm{~cm}$ thick, in silty clay bed of high terrace cutbank on Mary's R. Coll 1974 and subm by F L Fiene, ISGS. Comment (FLF): date verifies Woodfordian age for terraces.

ISGS-334. Rhoads site

$13,440 \pm 250$

Organic silt from Logan Co, $3 \mathrm{~km} \mathrm{~W}$ of Lincoln $\left(40^{\circ} 10^{\prime} \mathrm{N}, 89^{\circ} 25^{\prime}\right.$ $\mathrm{W}$ ). From 2.2 to $2.3 \mathrm{~m}$ depth in C3 soil horizon. Coll 1973 and subm by L R Follmer. Comment (LRF): date is max for Sawmill profile (Cumulic Haplaquoll) developed in alluvium, and also approximates end of outwash deposition and beginning of alluviation in Kickapoo Creek valley.

\section{ISGS-358. Byron Nuclear Power Plant Section}

$\mathbf{5 8 4 0} \pm 90$

Organic clay from Ogle Co, $5.6 \mathrm{~km} \mathrm{SW}$ of Byron $\left(42^{\circ} 04^{\prime} 26^{\prime \prime} \mathrm{N}, 89^{\circ}\right.$ $16^{\prime} 42^{\prime \prime} \mathrm{W}$ ). From lens of black clay resting on dolomite and overlain by $3 \mathrm{~m}$ gray, sandy, pebbly clay with modern soil developed at top. Coll 1975 by $\mathrm{H}$ B Willman and D R Kolata; subm by $\mathrm{H}$ B Willman. Comment (HBW): organic material was apparently carried down from modern soil and does not date red residual clay, which fills solution channels in top of Galena dolomite.

ISGS-378. Byron Cooling Tower Trench

Snail shells, (predominately Lymnaea) from Ogle Co, $6 \mathrm{~km}$ SSW of Byron $\left(42^{\circ} 04^{\prime} 26^{\prime \prime} \mathrm{N}, 89^{\circ} 16^{\prime} 42^{\prime \prime} \mathrm{W}\right.$ ) from silt unit, $1.2 \mathrm{~m}$ thick overlain and underlain by till. Coll 1975 by L R Follmer, R H Gilkeson, and T M Johnson; subm by $\mathrm{L} \mathrm{R}$ Follmer. Comment (LRF): date on shell from silt and correlation of paleosol remnant on overlying till with complete Sangamon soil profile in same locality identifies silt (unnamed) and till (Sterling) as Illinoian.

\section{ISGS-374. Mt Morris Core}

$35,600 \pm 1000$

Organic silt from Ogle Co, $1.5 \mathrm{~km} \mathrm{~S}$ of Mount Morris $\left(42^{\circ} 01^{\prime} 40^{\prime \prime} \mathrm{N}\right.$, $\left.89^{\circ} 25^{\prime} 53^{\prime \prime} \mathrm{W}\right)$. From organic silt unit overlying Ogle Till Member. Coll 1975 by L, R Follmer and R H Gilkeson; subm by L R Follmer. Comment (LRF): date correlates with age of Plano Silt Member. This 
material represents A horizon of unnamed soil, superimposed on Sangamon soil.

ISGS-401. Mobile-23 Core

$18,910 \pm 200$

Organic clay $\left(<4 \mu\right.$ fraction) from Ogle Co, $8 \mathrm{~km} \mathrm{~S}$ of Byron $\left(42^{\circ} 02^{\prime}\right.$ $\left.30^{\prime \prime} \mathrm{N}, 89^{\circ} 14^{\prime} 16^{\prime \prime} \mathrm{W}\right)$. From A horizon of buried soil. Coll 1975 by $\mathrm{R} \mathrm{H}$ Gilkeson and T M Johnson; subm by L R Follmer. Comment (LRF): sample taken from same stratigraphic position as ISGS-374: 35,600 \pm 1000 . Younger than expected date. Leached condition of overlying loess suggests that sample was contaminated by humic materials translocated from modern soil.

\section{Airport West Section series}

Organic silt from Rock Island Co, $3 \mathrm{~km} \mathrm{E}$ of Milan, $\left(41^{\circ} 26^{\prime} 12^{\prime \prime} \mathrm{N}\right.$, $\left.90^{\circ} 31^{\prime} 37^{\prime \prime} \mathrm{W}\right)$. From organic silt, $0.9 \mathrm{~m}$ thick, overlain by $12 \mathrm{~m}$ loess and underlain by silty clay. Coll 1975 by R C Anderson and L P Fay; subm by R C Anderson, Augustana Coll, Rock Island, Illinois.

ISGS-476.

$26,180 \pm 760$

From upper $4 \mathrm{~cm}$ of organic silt unit, directly below Peoria Loess.

ISGS-375.

$41,200 \pm 1600$

From lower $5 \mathrm{~cm}$ of organic silt unit.

General Comment (RCA): dates bracket interval when small pond existed on Illinoian till plain. ISGS-476 suggests that loess deposition may have begun during Farmdalian time.

\section{Fox Chain of Lakes Sediment series}

Marl, peaty muck, and organic clayey silts from cores in Fox Chain of Lakes sediment series. Coll by J A Lineback, D L Gross, and J T Wickham; subm by D L Gross, ISGS.

ISGS-379. 40 to $50 \mathrm{~cm}$, peat $1270 \pm 80$

ISGS-383. 80 to $90 \mathrm{~cm}$, marl $7810 \pm 100$

From Nippersink Lake, Lake Co, $0.7 \mathrm{~km}$ NE of McHenry $\left(42^{\circ} 24^{\prime} 30^{\prime \prime}\right.$ $\left.\mathrm{N}, 88^{\circ} 11^{\prime} 25^{\prime \prime} \mathrm{W}\right)$. From $94 \mathrm{~cm}$ core in channel of lake. Marl is overlain by $56 \mathrm{~cm}$ peat.

ISGS-380. 25 to $35 \mathrm{~cm}$

$$
\mathbf{7 0 0} \pm \mathbf{8 0}
$$

ISGS-394. 60 to $70 \mathrm{~cm}$

$860 \pm 100$

From Lake Marie, Lake Co, $3.2 \mathrm{~km} \mathrm{SW}$ of Antioch $\left(40^{\circ} 27^{\prime} 40^{\prime \prime} \mathrm{N}\right.$, $88^{\circ} 08^{\prime} 15^{\prime \prime} \mathrm{W}$ ). From $84 \mathrm{~cm}$ core of silt and clayey silt.

ISGS-381. 25 to $35 \mathrm{~cm}$ $1230 \pm 80$

ISGS-396. 54 to $64 \mathrm{~cm}$ $1240 \pm 80$

From Pistakee Bay, McHenry Co, $2.7 \mathrm{~km} \mathrm{SW}$ of Fox Lake $\left(42^{\circ} 22^{\prime}\right.$ $\left.20^{\prime \prime} \mathrm{N}, 88^{\circ} 13^{\prime} 05^{\prime \prime} \mathrm{W}\right)$. From $78 \mathrm{~cm}$ core of silts. 
ISGS-391. 25 to $35 \mathrm{~cm}$

$$
1770 \pm 130
$$

ISGS-390. 65 to $75 \mathrm{~cm}$

$1600 \pm 100$

From Lake Catherine, Lake Co, $1.3 \mathrm{~km}$ W of Antioch $\left(42^{\circ} 29^{\prime} 10^{\prime \prime} \mathrm{N}\right.$, $88^{\circ} 07^{\prime} 40^{\prime \prime} \mathrm{W}$ ). From $78 \mathrm{~cm}$ core of silt and silty clay.

\section{ISGS-395. 13 to $23 \mathrm{~cm}$ \\ $4250 \pm 120$ \\ ISGS-397. 45 to $55 \mathrm{~cm}$ \\ $5680 \pm 120$}

From Lake Marie, Lake Co, $3 \mathrm{~km} \mathrm{SW}$ of Antioch $\left(42^{\circ} 27^{\prime} 31^{\prime \prime} \mathrm{N}\right.$, $\left.88^{\circ} 07^{\prime} 55^{\prime \prime} \mathrm{W}\right)$. From $56 \mathrm{~cm}$ core of marl.

General Comment (DLG): dates indicate rapid sedimentation rate for silty clay, 2 or more $\mathrm{mm} / \mathrm{yr}$, and much slower rate for marl, ca $0.2 \mathrm{~mm} / \mathrm{yr}$. In areas where peaty muck overlay marl, contact between two materials may represent gap of several thousand yr. Geology of lakes is described by Kothandaraman et al (1977).

\section{Ruby Lane Section series}

Wood from St Clair Co, $8.7 \mathrm{~km} \mathrm{~N}$ of Belleville $\left(38^{\circ} 35^{\prime} 55^{\prime \prime} \mathrm{N}, 89^{\circ}\right.$ $59^{\prime} 45^{\prime \prime} \mathrm{W}$ ). From organic silt, lm thick, overlain and underlain by loess. Coll 1974 and subm by E D McKay, ISGS.
ISGS-294. Upper $15 \mathrm{~cm}$
$21,910 \pm 270$
ISGS-307. Lower $30 \mathrm{~cm}$
$23,930 \pm 280$

General Comment (EDM): organic silt from which samples were taken contains sediment mineralogically and sedimentalogically similar to overlying Peoria Loess and unlike underlying Roxana Silt. Thus, horizon is interpreted as early stage accumulation of loess related to later widespread Woodfordian loess deposition. ISGS-307, from lower portion of horizon, gives new min for initiation of Peoria Loess accumulation on bluffs of Mississippi Valley in SW Illinois.

\section{Canteen Creek Section series}

Site in St Clair Co, on $\mathrm{N}$ edge of Caseyville $\left(38^{\circ} 38^{\prime} 30^{\prime \prime} \mathrm{N}, 90^{\circ} 01^{\prime}\right.$ $\left.30^{\prime \prime} \mathrm{W}\right)$. Coll 1975 and subm by E D McKay.

ISGS-392.

$\mathbf{3 6 , 1 0 0} \pm \mathbf{5 5 0}$

Organic silt from organic zone, $0.75 \mathrm{~m}$ thick, within Roxana Silt.

\section{ISGS-393.}

$40,200 \pm 1500$

Wood from organic zone, $0.75 \mathrm{~m}$ thick, within Roxana silt.

ISGS-421.

$16,020 \pm 260$

Clay fraction $(<4 \mu)$ of loess from dark band at 4 to $5.7 \mathrm{~m}$ below top of Peoria Loess.

General Comment (EDM): ISGS-392 and -393 date lower portion of Zone III of Roxana Silt (Frye, Glass, and Willman, 1962). Previous age determinations on this horizon were made on gastropod shells, yielding dates between 35,000 to $37,000 \mathrm{BP}$, (W-729: $35,200 \pm 1000$, and $\mathrm{W}-869$ : 37,000 $\pm 1500, \mathrm{R}, 1960$, v 2, p 137-139; and ISGS-157: 35,750 $\pm 760, \mathrm{R}, 1974, v$ 
16, p 112). Younger than expected age for ISGS-392 may be due to postburial contamination and omission of base leach of sample to preserve enough datable material. ISGS-421 dates clay fraction of incipient soil (dark band) in Peoria Loess. Dated horizon may correlate with Jules Soil (Willman and Frye, 1970).

ISGS-400. Bunkum Borrow Pit Section

$30,980 \pm 400$

Gastropod shells from St Clair Co, $0.25 \mathrm{~km} \mathrm{E}$ of Bunkum $\left(38^{\circ} 37^{\prime} 08^{\prime \prime}\right.$ $\left.\mathrm{N}, 90^{\circ} 02^{\prime} 17^{\prime \prime} \mathrm{W}\right)$. From Meadow Loess Member of Roxana Silt. Coll 1975 and subm by E D McKay. Comment (EDM): gastropod shells coll from zone $0.75 \mathrm{~m}$ below top of Zone III of Roxana Silt (Frye, Glass, and Willman, 1968) yielded youngest available date on Roxana Silt. Previous age determinations on Roxana sediments were from stratigraphically lower horizons, usually in excess of 35,000 BP (ISGS-157, 1974, v 16, p 112). At this site, ca $25 \%$ of Roxana overlies dated horizon.

\section{Sugarloaf Road Core series}

Wood fragments and organic silt from Madison Co, $2.7 \mathrm{~km} \mathrm{~N}$ of Collinsville $\left(38^{\circ} 42^{\prime} 58^{\prime \prime} \mathrm{N}, 89^{\circ} 59^{\prime} 49^{\prime \prime} \mathrm{W}\right)$. Coll 1974 and subm by E D McKay.

ISGS-412. \#21.16

$20,910 \pm 520$

From interval 6.45 to $6.70 \mathrm{~m}$ below top of Peoria Loess, $9.6 \mathrm{~m}$ thick.

ISGS-413. \#27.25

$\mathbf{2 3 , 1 1 0} \pm \mathbf{8 0 0}$

From interval 8.35 to $8.50 \mathrm{~cm}$ below top of Peoria Loess, $9.6 \mathrm{~m}$ thick.

General Comment (EDM): ISGS-412 dates loess horizon ca $1.2 \mathrm{~m}$ below top of clay mineral Zone II (Frye, Glass, and Willman, 1968) of Peoria Loess. ISGS-413 dates loess horizon ca $0.2 \mathrm{~m}$ above base of Zone II, and confirms that age of base of Peoria Loess in SW Illinois exceeds 23,000 BP, as previously suggested by ISGS-307: 23,900 \pm 280 .

\section{Volo Bog Peat Core series}

Peat from Lake Co, $3.2 \mathrm{~km} \mathrm{~N}$ of Volo $\left(42^{\circ} 21^{\prime} 05^{\prime \prime} \mathrm{N}, 88^{\circ} 11^{\prime} 04^{\prime \prime} \mathrm{W}\right)$, from core taken in bog. Coll 1976 and subm by J B Risatti and J E King.

$\begin{array}{llr}\text { ISGS-462. } & 100 \text { to } 105 \mathrm{~cm} \text { depth } & 1050 \pm 100 \\ \text { ISGS-460. } & 265 \text { to } 272 \mathrm{~cm} \text { depth } & 2330 \pm 170 \\ \text { ISGS-461. } & 480 \text { to } 490 \mathrm{~cm} \text { depth } & 4680 \pm 150 \\ \text { ISGS-459. } & 600 \text { to } 610 \mathrm{~cm} \text { depth } & 6090 \pm 100 \\ \text { ISGS-451. } & 800 \text { to } 806 \mathrm{~cm} \text { depth } & 10,590 \pm 250 \\ \text { ISGS-463. } & 852 \text { to } 858 \mathrm{~cm} \text { depth } & 11,070 \pm 210\end{array}$

General Comment (JBR): dates helped determine when Volo Bog basin began to accumulate organic sediments. Dates, when related to pollen data, helped to establish climatologic events in bog's history and allowed determination of sedimentation rates from first accumulation of organic sediments to present (Risatti, 1977). 
Chatsworth (Strawn) Bog series

Marly lake sediments from Livingston Co, $6.5 \mathrm{~km}$ SW of Chatsworth $\left(40^{\circ} 40^{\prime} 32^{\prime \prime} \mathrm{N}, 88^{\circ} 20^{\prime} 34^{\prime \prime} \mathrm{W}\right)$, from $12.8 \mathrm{~m}$ core of lake sediment. Coll 1975 and 1977 by J E King and L R Follmer; subm by J E King, Illinois State Mus, Springfield.

$\begin{array}{llr}\text { ISGS-516. } & 105 \text { to } 110 \mathrm{~cm} \text { depth } & 3370 \pm 80 \\ \text { ISGS-517. } & 203 \text { to } 210 \mathrm{~cm} \text { depth } & 4160 \pm 90 \\ \text { ISGS-416. } & 395 \text { to } 400 \mathrm{~cm} \text { depth } & 5330 \pm 100 \\ \text { ISGS-417. } & 695 \text { to } 700 \mathrm{~cm} \text { depth } & 7680 \pm 100 \\ \text { ISGS-519. } & 962 \text { to } 968 \mathrm{~cm} \text { depth } & 8300 \pm 100 \\ \text { ISGS-526. } & 1111 \text { to } 1119 \mathrm{~cm} \text { depth } & 10,860 \pm 80 \\ \text { ISGS-528. } & 1151 \text { to } 1159 \mathrm{~cm} \text { depth } & 11,280 \pm 110 \\ \text { ISGS-527. } & 1250 \text { to } 1260 \mathrm{~cm} \text { depth } & 14,380 \pm 150\end{array}$

General Comment (JEK): dates indicate that spruce woodland and tundra occurred in area until ca 14,000 BP and that deciduous forest was established by 10,500 BP. Prairie vegetation first developed ca 8300 BP, and has persisted to present. Radiocarbon dates of Chatsworth pollen assemblage zones agree with those from other Illinois sites.

\section{Monticello Borrow Pit Section series}

Organic silt from Piatt Co, $3 \mathrm{~km} \mathrm{~N}$ of Monticello $\left(40^{\circ} 02^{\prime} 19^{\prime \prime} \mathrm{N}\right.$, $88^{\circ} 34^{\prime} 56^{\prime \prime} \mathrm{W}$ ). Coll 1975 by W H Johnson and J E King; subm by W $\mathrm{H}$ Johnson.

ISGS-408.

$28,970 \pm 290$

Bulk sample from $40 \mathrm{~cm}$ below top of Robein Silt. Comment (WHJ): date and well-preserved pollen from $1.3 \mathrm{~m}$ organic deposit indicate presence of pollen record for substantial interval prior to Woodfordian glaciation.

ISGS-422. Core WHJ-76-1

$22,850 \pm 290$

From upper $10 \mathrm{~cm}$ of $55 \mathrm{~cm}$ thick Robein Silt.

ISGS-490. Core WHJ-77-16

$34,290 \pm 840$

From 26 to $30 \mathrm{~cm}$ below top of Robein Silt.

ISGS-447. Core WHJ-77-13

$>\mathbf{3 4 , 2 0 0}$

From upper $5 \mathrm{~cm}$ of $110 \mathrm{~cm}$ thick Roxana Silt(?).

ISGS-423. Core WHJ-76-2

$37,950 \pm 700$

From lower $20 \mathrm{~cm}$ of $110 \mathrm{~cm}$ thick Roxana Silt(?).

General Comment (WHJ): sequence of dates is not compatible with conformable sedimentation record. Upper (ISGS-422) and lower (ISGS-423) dates are considered most accurate and will be utilized in interpretation 
of pollen record. Middle two dates (ISGS-490 and -447) appear to be too old and probably contain detrital organic material derived from Paleozoic bedrock.

ISGS-426. Geneseo Landfill Core

$13,300 \pm 240$

Wood fragments from Henry Co, $1.8 \mathrm{~km} \mathrm{~N}$ of Geneseo $\left(41^{\circ} 28^{\prime} 41^{\prime \prime}\right.$ $\mathrm{N}, 90^{\circ} 09^{\prime} 21^{\prime \prime} \mathrm{W}$ ). From organic silt unit 6.1 to $6.5 \mathrm{~m}$ from top of core. Unit is overlain by dune sand and underlain by outwash sand. Coll 1976 and subm by $\mathrm{T}$ M Johnson, ISGS. Comment (TMJ): only known date immediately beneath sand dunes in Green River Lowland. Site underlain by Sterling Till Member.

\section{Anna-Jonesboro Test Site series}

Carbonized wood from Union Co, $0.8 \mathrm{~km} \mathrm{~N}$ of Pottsville $\left(37^{\circ} 25^{\prime} 45^{\prime \prime}\right.$ N, $89^{\circ} 21^{\prime} 31^{\prime \prime}$ W). Coll 1976 by J T Ruester; subm by P C Reed, ISGS.

ISGS-453.

$1970 \pm 80$

From log buried in valley train sand and gravel at depth $13.7 \mathrm{~m}$.

ISGS-454.

$2060 \pm 90$

From depth $23 \mathrm{~m}$ below surface.

General Comment (PCR): dates give information on rate of sedimentation and agree with other Holocene data, IJ-281: $6600 \pm 200$ (Willman and Frye, 1970). Nearly identical dates on ISGS-453 and -454 suggest that latter may have been carried down to deeper location during drilling.

ISGS-521. Inlet Swamp

$6460 \pm 110$

Wood from Lee Co, $3.2 \mathrm{~km} \mathrm{~S}$ of Rochelle $\left(41^{\circ} 46^{\prime} 47^{\prime \prime} \mathrm{N}, 89^{\circ} 04^{\prime} 08^{\prime \prime}\right.$ W). From top of gray sandy silt, 1.47 to $1.63 \mathrm{~m}$ depth. Coll 1976 and subm by $\mathrm{S} E$ Zwicker, Soil Conservation Service, Amboy, Illinois. Comment (SEZ): site is in ancient glacial lake. Sediments are younger than expected. Date helps to establish age relationship of outwash of Tiskilwa Till Member $\mathrm{E}$ of lake bed and serves as benchmark for degree of soil development.

\section{Stubbe Farm series}

Peat from Stephenson Co, $2.7 \mathrm{~km}$ SSE of Winslow $\left(42^{\circ} 28^{\prime} 15^{\prime \prime} \mathrm{N}\right.$, $89^{\circ} 46^{\prime} 47^{\prime \prime} \mathrm{W}$ ). Coll 1977 and 1978 by G R Whittecar and L R Follmer; subm by $\mathrm{G} R$ Whittecar, Univ Wisconsin, Madison.

ISGS-561.

$$
\mathbf{2 6 , 8 2 0} \pm \mathbf{2 0 0}
$$

From 5.01 to $5.17 \mathrm{~m}$ below surface, at top of peat unit $1.8 \mathrm{~m}$ thick. Comment (GRW): peat is in high-level terrace that contains stony silty diamicton believed to be periglacial solifluction deposit. Date indicates time that peat growth stopped.

ISGS-479.

From $4.5 \mathrm{~m}$ below surface, near base of peat bed, $1.5 \mathrm{~m}$ thick. Comment (GRW): date is max for overlying glaciolacustrine sediments and loess in terraces along this reach of Pecatonica R. 
ISGS-562.

$40,500 \pm 1700$

From base of peat unit, 6.98 to $7.04 \mathrm{~m}$ below surface. Comment (GRW): date indicates end of diamicton deposition.

\section{Gardena series}

Site in Tazewell Co, $1 \mathrm{~km} \mathrm{~S}$ of Sunnyland $\left(40^{\circ} 40^{\prime} 15^{\prime \prime} \mathrm{N}, 89^{\circ} 28^{\prime} 53^{\prime \prime}\right.$ W). Coll 1978 by E D McKay and L R Follmer; subm by L R Follmer.

ISGS-532.

$19,680 \pm 460$

Wood from top of Morton Loess.

ISGS-530.

$25,680 \pm 1000$

Wood from Morton Loess.

ISGS-531.

$25,370 \pm 310$

Wood from base of Morton Loess.

ISGS-529.

$25,960 \pm 280$

Organic silt with wood chips from upper $10 \mathrm{~cm}$ Roxana Silt.

General Comment (LRF): series of dates reconfirms previous interpretations of classic Farm Creek Section with adjustment in chronologic interpretation. The mid-Wisconsinan interstadial, the Farmdalian Substage, was terminated at ca 25,000 BP by first deposition of Morton Loess. Morton is loess that was generated in response to advance of Woodfordian glaciers and subsequently buried by Woodfordian till at ca $20,000 \mathrm{BP}$ at this locality and other areas along Woodfordian glacial margin in Midwest (Follmer et al, 1979).

\section{Farm Creek-East series}

Organic silt with wood fragments from Tazewell Co, Farmdale Park, S of Sunnyland $\left(40^{\circ} 40^{\prime} 43^{\prime \prime} \mathrm{N}, 89^{\circ} 29^{\prime} 18^{\prime \prime} \mathrm{W}\right)$. Coll 1978 by L R Follmer and E D McKay; subm by L R Follmer.

ISGS-533.

$26,680 \pm 380$

From near top of Robein Silt.

ISGS-535.

$\mathbf{2 7 , 7 0 0} \pm \mathbf{7 7 0}$

From base of Robein Silt.

General Comment (LRF): samples are from type sec of Robein Silt. Previous dates from nearby exposures are younger (W-68: 22,900 \pm 900; W-69: $25,100 \pm 800$ ). Here, Robein represents organic matter accumulation during mid-Wisconsinan time, named from this exposure, Farmdalian Substage (Follmer et al, 1979).

\section{Athens North Quarry series}

Site in Menard Co, $6.5 \mathrm{~km}$ NNE of Athens $\left(40^{\circ} 00^{\prime} 44^{\prime \prime} \mathrm{N}, 89^{\circ} 42^{\prime}\right.$ 16" W). Coll 1978 and 1979 by L R Follmer and E D McKay; subm by L R Follmer. 
ISGS-534.

$$
22,170 \pm 450
$$

Wood from top of basal third of Peoria Loess, approx in middle of dolomite zone P-3 (Follmer et al, 1979). Wood and needles preserved below this level. Comment (LRF): stratigraphy indicates that Farmdale Soil environment continued into Peoria Loess depositional event.

ISGS-536.

$25,170 \pm 200$

Spruce wood and organic silt from wood and needle litter horizon described as Robein Silt. Underlies Peoria Loess and overlies Roxana Silt. Comment (LRF): date agrees reasonably well with dates from type sec (ISGS-533) and other locations (ISGS-529, -531, -575, -653, and -656). Indicates that Robein Silt was buried ca 25,000 BP.

ISGS-654. Pit 3E 6-6.2m

$38,920 \pm 1100$

Organic silt ( $<5 \mu$ fraction) from near middle of Roxana Silt. Comment (LRF): sample dates soil-forming event within Roxana deposition.

ISGS-546. Amos Edwards Farm Section

$21,460 \pm 210$

Organic silty clay from Gallatin Co, $7.4 \mathrm{~km} \mathrm{NW}$ of Ridgeway $\left(37^{\circ}\right.$ $\left.51^{\prime} 01^{\prime \prime} \mathrm{N}, 88^{\circ} 18^{\prime} 24^{\prime \prime} \mathrm{W}\right)$. From depth $8 \mathrm{~m}$ in borehole from Unit $30 \mathrm{~b}$, Equality Formation. Coll 1978 and subm by P V Heinrich, Univ Illinois. Comment (PVH): date indicates that brown, moderate illite content (50 to $52 \%$ ) sediments at base of Unit $30 \mathrm{~b}$ are earliest Woodfordian; dates beginning of transition from massive to laminated sediments in sec.

ISGS-547. Mitchell Farm Section

$20,510 \pm 170$

Organic clayey silt from Hamilton Co, $2.6 \mathrm{~km}$ NE of Broughton $\left(37^{\circ} 57^{\prime} 29^{\prime \prime} \mathrm{N}, 88^{\circ} 26^{\prime} 02^{\prime \prime} \mathrm{W}\right)$. From top of Unit 30a, Equality Formation, at depth $5.7 \mathrm{~m}$ in borehole. Coll and subm by $\mathrm{P} V$ Heinrich. Comment (PVH): this date, with ISGS-546, demonstrates that contact between Unit $30 \mathrm{a}$ and $30 \mathrm{~b}$ is time-transgressive along North Fork $\mathrm{R}$. Time-transgressive nature of contact explains why color and mineralogic zone in Unit 30b in Amos Edwards Farm Section is missing in this sec.

ISGS-548. Sadler Farm Section

$3940 \pm 80$

Pelecypod shell fragments from Saline Co, $3.4 \mathrm{~km} \mathrm{E}$ of Harrisburg $\left(37^{\circ} 44^{\prime} 18^{\prime \prime} \mathrm{N}, 88^{\circ} 29^{\prime} 54^{\prime \prime} \mathrm{W}\right)$, from shell lens in silty clay of Unit $30 \mathrm{~b}$, Equality Formation. Coll 1978 and subm by P V Heinrich. Comment (PVH): date is too young for stratigraphic position in Unit $30 \mathrm{~b}$ of Equality Formation. Sediments of overlying Unit 50 of Equality Formation have been dated ca 13,000 BP (ISGS-101 and -103: R, 1973, v 15, p 81). Also, base of Unit 30b along Middle Fork $R$ dates ca 21,000 BP: (ISGS-84 and -87: R, 1973, v 15, p 80).

ISGS-549. Barnes Farm Section

$21,780 \pm 410$

Organic silt from Saline Co, $1.4 \mathrm{~km} N$ of Dorris Heights $\left(88^{\circ} 33^{\prime} 45^{\prime \prime}\right.$ $\mathrm{N}, 37^{\circ} 47^{\prime} 00^{\prime \prime} \mathrm{W}$ ), from Unit $30 \mathrm{a}$ ca $0.75 \mathrm{~m}$ below Unit $30 \mathrm{a}-30 \mathrm{~b}$ contact, Equality Formation. Coll 1978 and subm by $\mathrm{P}$ V Heinrich. Comment (PVH): date, with ISGS-84 and -87, demonstrates that Unit $30 \mathrm{a}$ and $30 \mathrm{~b}$ 
contact is not noticeably time-transgressive along Middle Fork R. Date suggests that circulation from valley train into upper reaches of Middle Fork $\mathrm{R}$ was established at earlier date and faster rate than along North Fork R.

\section{Big Rock Creek series}

Organic silt from Kendall Co, $8.9 \mathrm{~km}$ NW of Yorkville $\left(88^{\circ} 29^{\prime} 30^{\prime \prime}\right.$ $\left.\mathrm{N}, 41^{\circ} 42^{\prime} 45^{\prime \prime} \mathrm{W}\right)$. Coll 1978 by S S Wickham and M M Killey; subm by S S Wickham, ISGS.

ISGS-557.

$40,500 \pm 1100$

From Plano Silt Member, 4.5 to $4.95 \mathrm{~m}$ below surface.

ISGS-559.

$40,400 \pm 1400$

From base of Plano Silt Member, 4.95 to $6.4 \mathrm{~m}$ below surface.

General Comment (SSW): dates confirm Altonian age for Plano Silt Member of Winnebago Formation.

ISGS-560. Zip Profile \#23

$20,830 \pm 160$

Soil ( $<4 \mu$ fraction) from Hamilton Co, $2 \mathrm{~km} \mathrm{NE}$ of Broughton $\left(37^{\circ}\right.$ $\left.57^{\prime} 21^{\prime \prime} \mathrm{N}, 88^{\circ} 26^{\prime} 57^{\prime \prime} \mathrm{W}\right)$. From organic silt zone within Equality Formation. Coll 1977 by L R Follmer and B Currie; subm by L R Follmer. Comment (LRF): sample dates low-water stage in Lake Saline, glacial slack water lake of Woodfordian age.

\section{Horseshoe Lake series}

Silty clay lake sediment from Madison Co, $5 \mathrm{~km}$ SW of Granite City (38 $41^{\prime} 43^{\prime \prime}$ N, $\left.90^{\circ} 04^{\prime} 12^{\prime \prime} \mathrm{W}\right)$. Coll 1977 and subm by D L Gross.

$\begin{array}{llr}\text { ISGS-574. } & \text { Core depth, } 6.25 \text { to } 6.5 \mathrm{~m} & 3010 \pm 100 \\ \text { ISGS-563. } & \text { Core depth, } 9 \text { to } 9.3 \mathrm{~m} & 3270 \pm 80\end{array}$ General Comment (DLG): Horseshoe Lake is oxbow meander of Mississippi R. Dates provide time of cutoff from Mississippi $\mathrm{R}$ and allow calculation of long-term average sedimentation rate of ca $2 \mathrm{~mm} / \mathrm{yr}$.

\section{ISGS-575. Troy Auger-12.0 \\ $26,050 \pm 330$}

Muck and wood from Madison Co, $1 \mathrm{~km} \mathrm{SW}$ of Troy $\left(38^{\circ} 41^{\prime} 36^{\prime \prime} \mathrm{N}\right.$, $\left.89^{\circ} 54^{\prime} 06^{\prime \prime} \mathrm{W}\right)$, from top of Roxana Silt. Coll 1979 and subm by E D McKay. Comment (EDM): dates upper $15 \mathrm{~cm}$ of Farmdale Soil developed in Roxana Silt. Date is max at this site for burial of Roxana Silt with Peoria Loess, and agrees with dates of surface horizon of Farmdale Soil from its type area, (ISGS-529 and -533).

ISGS-594. Pleasant Grove School

$26,050 \pm 370$

Organic component of clay ( $<4 \mu$ fraction) extracted from loess from Madison Co, $1.7 \mathrm{~km} \mathrm{~N}$ of Collinsville $\left(38^{\circ} 41^{\prime} 34^{\prime \prime} \mathrm{N}, 90^{\circ} 00^{\prime} 26^{\prime \prime} \mathrm{W}\right)$. From 0.7 to $1.1 \mathrm{~m}$ below top of "zone r-2" (McKay, 1979a) in lower part of Roxana Silt. Coll 1979 by E D McKay and L R Follmer; subm by E D McKay. Comment (EDM): approx same horizon as dated by W-729: 
$35,200 \pm 1000$, at this location. "Zone r-2" in Canteen Creek Section, $6 \mathrm{~km}$ to $S$ is overlain by peat bed dated by ISGS-393: 40,200 \pm 1500 , and ISGS392: $36,100 \pm 550$. Serious disparity among these dates and ISGS-594 suggest sample was contaminated with younger carbon.

ISGS-614. Malden South II

Wood from Bureau Co, $3.2 \mathrm{~km} \mathrm{~S}$ of Malden $\left(41^{\circ} 23^{\prime} 35^{\prime \prime} \mathrm{N}, 89^{\circ} 21^{\prime}\right.$ $30^{\prime \prime}$ W). From Robein Silt, $0.6 \mathrm{~m}$ from top. Coll 1979 by S S Wickham and Inez Kettles; subm by S S Wickham. Comment (SSW): date agrees well with other dates of Robein in N Illinois: (I-1625, I-2220, and W-333; Willman and Frye, 1970).

\section{ISGS-624. Amboy West}

$37,290 \pm 790$

Organic silt from Lee Co, $4.7 \mathrm{~km}$ WSW of Amboy $\left(41^{\circ} 43^{\prime} 27^{\prime \prime} \mathrm{N}\right.$, $89^{\circ} 24^{\prime} 10^{\prime \prime} \mathrm{W}$ ), from soil developed in silt. Coll 1979 and subm by S E Zwicker. Comment (SEZ): sediments encountered are older than previously correlated. Date verifies pre-Woodfordian age of soils developed in Lee Center Till Member.

\section{ISGS-649. Miller's Farm}

$$
\begin{gathered}
20,160 \pm 250 \\
\delta^{1 s} C=-25.1 \% \text { o }
\end{gathered}
$$

Wood fragments from Union Co, $4 \mathrm{~km} \mathrm{E}$ of Wolf Lake $\left(37^{\circ} 30^{\prime} 15^{\prime \prime}\right.$ $\mathrm{N}, 89^{\circ} 26^{\prime} 10^{\prime \prime} \mathrm{W}$ ), from blue-gray silty clay lacustrine deposit. Coll 1979 and subm by D R Fraser, Southern Illinois Univ. Comment (DRF): date is from near base of mid-Woodfordian slackwater lake deposits in Hutchins Creek-Clear Creek valley; agrees well with dates from similar lake deposits in Saline R Valley (Frye et al, 1972).

\section{ISGS-650. Rhodes Farm}

$270 \pm 80$

Wood fragments from Union Co, $4 \mathrm{~km} \mathrm{E}$ of Wolf Lake $\left(37^{\circ} 30^{\prime} 15^{\prime \prime}\right.$ $\left.\mathrm{N}, 89^{\circ} 26^{\prime} 10^{\prime \prime} \mathrm{W}\right)$, from cut bank on Clear Creek, in gray sandy loam with lacustrine structures. Coll 1979 and subm by D R Fraser. Comment (DRF): date provides information on rate of floodplain deposition; change in sediment characteristics just above dated horizon may be result of frontier settlement.

\section{Pekin Sewer Site series}

Wood chips and silty muck from Tazewell Co, at E edge of Pekin $\left(40^{\circ} 32^{\prime} 59^{\prime \prime} \mathrm{N}, 89^{\circ} 35^{\prime} 36^{\prime \prime} \mathrm{W}\right)$. Coll 1979 by L R Follmer and E D McKay; subm by L R Follmer.

ISGS-662.

From uppermost wood-rich zone, $6.3 \mathrm{~m}$ below surface.

ISGS-661.

From lowermost wood-rich zone, 6.75 to $6.85 \mathrm{~m}$ below surface.

General Comment (LRF): dates agree with dates of ISGS-533 and -535 determined on Robein Silt at its type sec, $16 \mathrm{~km}$ NNE of this site. Interval 
sampled represents time of organic soil formation between depositional events. Based on youthful profile characteristics of Farmdale Soil developed in and through Robein Silt, it is believed that dates give a reasonable estimate of beginning and end of soil formation at this site.

\section{Chapel Hill Section series}

$$
\text { C. Iowa }
$$

Peat from Scott Co, on W edge of Davenport $\left(41^{\circ} 29,30^{\prime \prime} \mathrm{N}, 90^{\circ} 39^{\prime}\right.$ $00^{\prime \prime} \mathrm{W}$ ). From silty peat channel-fill lying unconformably on materials as old as Glasford Formation; peat is overlain by Robein Silt, continuous across and beyond limits of channel. Coll 1970 and subm by R C Anderson.

ISGS-243.

$27,500 \pm 800$

Peat from near top of peaty channel fill. Comment (RCA): date is early Farmdalian, and together with ISGS-244 (>39,300 BP) from near base of channel-fill, indicates that channel-fill began to accumulate prior to Farmdalian time, probably in broad, open valley that was later occupied and enlarged by Mississippi R.

ISGS-244.

$>\mathbf{3 9 , 3 0 0}$

From lower portion of channel-fill, $1.2 \mathrm{~m}$ below peat dated by ISGS243. Comment (RCA): date indicates that channel was cut and began to be filled before 39,300 BP. Sample might be as old as Sangamonian or even Illinoian and suggests that topographic sag, perhaps in form of an abandoned channel, existed prior to establishment of present course of Mississippi R during Woodfordian time.

ISGS-503. Sheldon Transect

$31,100 \pm 2000$

Silt from O'Brien Co, $2.9 \mathrm{~km} \mathrm{SE}$ of Sheldon $\left(43^{\circ} 09^{\prime} 30^{\prime \prime} \mathrm{N}, 95^{\circ} 48^{\prime}\right.$ $45^{\prime \prime}$ W). From oxidized and unleached organic band overlying Wisconsinan loess and underlying Tazewell till and outwash. Coll 1976 and subm by G R Hallberg, Iowa Geol Survey, Iowa City. Comment (GRH): radiocarbon dates from this area are problematic: date is split of sample dated at $4090 \pm 120$ (I-9895; Ruhe, 1969). Both samples are from similar stratigraphic position as sample dated at $20,500 \pm 400$ (I-1864A; Ruhe, 1969).

ISGS-512. Garnavillo

$25,300 \pm 650$

Loess from Clayton Co, $0.4 \mathrm{~km} \mathrm{NE}$ of Garnavillo $\left(42^{\circ} 51^{\prime} 45^{\prime \prime} \mathrm{N}, 91^{\circ}\right.$ $13^{\prime} 45^{\prime \prime} \mathrm{W}$ ). From depth 5 to $5.4 \mathrm{~m}$ in "basal Wisconsinan" loess paleosol. Coll 1977 and subm by G R Hallberg. Comment (GRH): data from basal loess paleosol mark beginning of deposition of Wisconsinan loess in NE Iowa, near Mississippi R.

ISGS-552. Cook's Quarry

$13,680 \pm 80$

Wood from Story Co, $3 \mathrm{~km} \mathrm{NE}$ of Ames $\left(42^{\circ} 03^{\prime} 56^{\prime \prime} \mathrm{N}, 93^{\circ} 35^{\prime} 48^{\prime \prime}\right.$

W), from depth $10.4 \mathrm{~m}$ in unoxidized, jointed, unleached "Cary" till.

Coll 1978 by G R Hallberg, T J Kemmis, and A Lutenegger; subm by 
G R Hallberg. Comment (GRH): wood is from base of late Wisconsinan till, and is from same stratigraphic horizon as some earlier, questionable carbon-black dates; C-596: 11,952 \pm 500 and C-653: 12,200 \pm 500 (Ruhe, 1969). Date fits chronology established by other recent dates.

ISGS-553. LeGrand-Anderson Quarry

$24,500 \pm 820$

Organic loess from Tama Co, $3 \mathrm{~km}$ NE of LeGrand $\left(42^{\circ} 01^{\prime} 05^{\prime \prime} \mathrm{N}\right.$, $92^{\circ} 43^{\prime} 32^{\prime \prime} \mathrm{W}$ ), from paleosol in basal Wisconsinan loess. Coll 1978 by G R Hallberg, A Lutenegger, and T J Kemmis; subm by G R Hallberg. Comment (GRH): date marks beginning of significant Wisconsinan loess deposition in area and agrees with other basal loess dates in area around Iowa $\mathbf{R}$.

ISGS-641. Algona

$12,610 \pm 250$

Wood fragment from Kossuth Co, Algona $\left(43^{\circ} 05^{\prime} \mathrm{N}, 94^{\circ} 14^{\prime} \mathrm{W}\right)$. From unoxidized, unleached jointed loam till (Algona Moraine). Coll 1978 by $\mathrm{T}$ J Kemmis and R Jones; subm by $\mathrm{G} R$ Hallberg. Comment $(\mathrm{GRH})$ : date, with other recent dates from deposits of Algona Moraine, are all in range of ca 12,000 to 12,600 BP. Dates place deposits of Algona Moraine of Des Moines Lobe at younger age than previously assumed (Ruhe, 1969).

\section{Schelke Bog series}

\section{Wisconsin}

Organic silt from Lincoln Co, $0.5 \mathrm{~km} \mathrm{E}$ of Doering $\left(45^{\circ} 14^{\prime} 10^{\prime \prime} \mathrm{N}\right.$, $\left.89^{\circ} 26^{\prime} 55^{\prime \prime} \mathrm{W}\right)$. Coll 1973 and subm by D M Mickelson, Univ Wisconsin, Madison.

ISGS-262.

Silt from beneath Woodfordian drift, 12.07 to $12.23 \mathrm{~m}$ below surface. Marks change from high Pinus pollen below to high Picea pollen above.

ISGS-256.

$40,800 \pm 2000$

Silt from depth 12.32 to $12.39 \mathrm{~m}$ in organic sand and silt zone overlying Merrill Till.

General Comment (DMM): dates are min for Merrill Till. Outwash above dated horizons is probably Woodfordian but could, at least in part, be late Altonion. Because Merrill Till is surficial till in this area, dates suggest that late Altonion advance (Rockian) did not extend as far as Woodfordian end moraines $10 \mathrm{~km}$ to $\mathrm{N}$.

\section{Two Creeks series}

Wood from Kewaunee Co, $3.3 \mathrm{~km}$ NNE of Two Creeks $\left(44^{\circ} 19^{\prime} 38^{\prime \prime}\right.$ $\mathrm{N}, 87^{\circ} 32^{\prime} 15^{\prime \prime} \mathrm{W}$ ), from Two Creeks forest bed. Sample from part of stump in situ with roots penetrating into underlying sediments. Coll 1973 and subm by $\mathrm{D} D$ Coleman.

ISGS-264A. Split 1

$$
11,790 \pm 80
$$


ISGS-264B. Split 2

$11,640 \pm 90$

General Comment: dates agree well with each other and with average for this site determined by various laboratories.

ISGS-480. DePere Forest Bed

$11,980 \pm 100$

Wood from Brown Co, $6.9 \mathrm{~km}$ SE of DePere $\left(44^{\circ} 24^{\prime} 40^{\prime \prime} \mathrm{N}, 88^{\circ} 00^{\prime}\right.$

$17^{\prime \prime} \mathrm{W}$ ), from forest bed overlain by red clayey till and underlain by stratified sand and red clayey till. Coll 1977 and subm by T A Kessenich, Univ Wisconsin, Madison. Comment (TAK): Twocreekan age of sample demonstrates at least two episodes of red till deposition in Green Bay lowland; one pre-Twocreekan and one post-Twocreekan. Stratigraphic relationship of tills and age of sample agrees with similar deposits near Appleton, Wisconsin, (L-698-B) (Black, 1976).

\section{New Denmark series}

Wood from Brown Co. Coll 1979 by R D Steiglitz, J Moran, and D Quigley; subm by R D Steiglitz, Univ Wisconsin-Green Bay.

ISGS-659.

ISGS-666.

from forest bed in red till, 4.6 to $4.7 \mathrm{~m}$ below surface.

ISGS-660.

$11,630 \pm 80$

$11,640 \pm 80$

$\delta^{1 s} C=-26.1 \%$

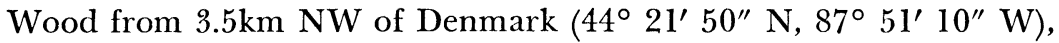
from thin bed containing wood and fine organic silt, 4.5 to $4.6 \mathrm{~m}$ below surface.

General Comment (RDS): samples from topographically high site NW of intersection of Denmark and Interlobate Moraines of late Wisconsinan age. Dates may be at contact of older Chilton or Branch River Tills and younger Glenmore till and may help establish time of last advance of Green Bay Lobe ice into area.

ISGS-558. Bollant Site

$20,270 \pm 650$

Organic materials (peat-like) from Grant Co, $8 \mathrm{~km}$ WNW of Livingstone $\left(42^{\circ} 56^{\prime} \mathrm{N}, 90^{\circ} 30^{\prime} \mathrm{W}\right)$, from lower portion of sandy silt zone, 8.8 to $10.4 \mathrm{~m}$ below surface in alluvial fan. Coll 1978 and subm by J C Knox, Univ Wisconsin, Madison. Comment (JCK): date supports hypothesis that present alluvial fans in Driftless Area have developed since early Woodfordian time. Alluvial fan deposits at dated site and in other Driftless Area alluvial fans imply that intense surface runoff and related large floods probably were extremely rare during Woodfordian time. 


\section{E. Indiana}

\section{Lake Turman series}

Wood fragments from Sullivan Co, $4.8 \mathrm{~km}$ SSE of Fairbanks $\left(39^{\circ} 10^{\prime}\right.$ $42^{\prime \prime} \mathrm{N}, 87^{\circ} 30^{\prime} 16^{\prime \prime} \mathrm{W}$ ), from drill core $12.6 \mathrm{~m}$ long. Coll 1973 by L E Hall; subm by R V Ruhe, Indiana Univ.

ISGS-247. Core depth, 5.2 to $5.5 \mathrm{~m}$

$$
9220 \pm 210
$$

ISGS-248. Core depth, 11.5 to $11.6 \mathrm{~m}$

$9010 \pm 190$

General Comment (RVR): dates show that Lake Turman deposits are of Holocene age, not Wisconsinan or "Upper Pleistocene," as previously believed.

ISGS-382. Ardmore Road Quarry

$21,310 \pm 350$

Plant debris in silty sand from Allen Co, SW of $\mathrm{Ft}$ Wayne $\left(41^{\circ} 01^{\prime}\right.$ $\left.30^{\prime \prime} \mathrm{N}, 87^{\circ} 12^{\prime} 00^{\prime \prime} \mathrm{W}\right)$. Coll 1974 and subm by M C Moore, Indiana Geol Survey, Bloomington. Comment (MCM): dates are max for readvance of ice that deposited till of Trafalgar Fm (Wayne, 1963) in NE Indiana. Detailed stratigraphy of site has been discussed by Bleuer and Moore (1971; 1972) and Moore and Bleuer (1972).

ISGS-386. Middle Prairie Creek

$\mathbf{3 6 , 3 8 0} \pm \mathbf{8 0 0}$

Wood from Fountain Co, $10 \mathrm{~km}$ SW of Veedersburg $\left(40^{\circ} 01^{\prime} 44^{\prime \prime} \mathrm{N}\right.$, $87^{\circ} 19^{\prime} 20^{\prime \prime} \mathrm{W}$ ), from within Glenburn (?) Till. Coll 1974 and subm by N K Bleuer, Indiana Geol Survey, Bloomington. Comment (NKB): dates are max for this surface till of Lake Michigan Lobe source, in area apparently not reached by $\mathrm{E}$ ice. Till is probably correlative with Glenburn Till Member of Wedron Fm, as mapped in Illinois.

ISGS-378. Russellville Section

$21,100 \pm 200$

Organic debris in silt from Putnam Co, $0.8 \mathrm{~km}$ SSW of Russellville $\left(39^{\circ} 50^{\prime} 44^{\prime \prime} \mathrm{N}, 86^{\circ} 59^{\prime} 14^{\prime \prime} \mathrm{W}\right)$, from loamy silt overlain and underlain by till. Coll 1975 by N K Bleuer, D L Eggert, and M C Moore; subm by N K Bleuer. Comment (NKB): dates are max for base of Trafalgar Fm in this area, and complement dates derived much earlier from similar sites in region as tabulated by Wayne (1965).

\section{Russellville Quarry series}

Wood from Putnam Co, $0.8 \mathrm{~km} \mathrm{~S}$ of Russellville $\left(39^{\circ} 51^{\prime} 37^{\prime \prime} \mathrm{N}, 86^{\circ}\right.$ $\left.58^{\prime} 30^{\prime \prime} \mathrm{W}\right)$. Sec is $5.9 \mathrm{~m}$ of till over organic silt, $15 \mathrm{~m}$ thick, which overlies Sangamon Soil, 1.8m thick, in lower Illinois till. Coll 1977 by R V Ruhe and C G Olson; subm by R V Ruhe.

ISGS-475. Depth 5.1m

ISGS-477. Depth 6.9m

$$
20,110 \pm 360
$$

$21,010 \pm 350$

General Comment (RVR): dates confirm upper till as Tazewell and organic silt as representative of time-transgressive Farmdale Soil. 
ISGS-388. Hillsdale North

Wood and plant fragments from Vermillion Co, $1 \mathrm{~km}$ NNW of Hillsdale $\left(39^{\circ} 47^{\prime} 28^{\prime \prime} \mathrm{N}, 87^{\circ} 23^{\prime} 44^{\prime \prime} \mathrm{W}\right)$. From silt unit, $0.4 \mathrm{~m}$ thick, overlain and underlain by till. Coll 1975 and subm by N K Bleuer. Comment $(\mathrm{NKB})$ : date tends to verify conclusion based on petrography that near-surface tills in area are pre-Wisconsinan. Dated silt occurs between tills that are probably Kansan.

ISGS-431. American Aggregates

Wood from Wayne Co, at NE edge of Richmond $\left(39^{\circ} 47^{\prime} \mathrm{N}, 84^{\circ} 46^{\prime}\right.$ $30^{\prime \prime} \mathrm{W}$ ), from silt and fine sand zone ca $0.6 \mathrm{~m}$ thick. Coll 1972 and subm by R P Goldthwait, Ohio State Univ.

ISGS-455. Cass Co, Well \#108

$21,610 \pm 310$

Wood fragments (Picea), from Cass Co, $6 \mathrm{~km}$ NNW of Logansport $\left(40^{\circ} 47^{\prime} 35^{\prime \prime} \mathrm{N}, 86^{\circ} 27^{\prime} 00^{\prime \prime} \mathrm{W}\right)$, from $\log$ penetrated by rotary drill bit at depth $52.5 \mathrm{~m}$, within till. Coll 1976 and subm by M C Moore. Comment (NKB): all overlying tills appear to be E-source Trafalgar Till. Extreme thickness $(52 \mathrm{~m})$ of overlying till must be valley fill of proto-Wabash $\mathrm{R}$ (pre-Trafalgar valley cut into older glacial materials). Together with ISGS-382: $21,310 \pm 350 \mathrm{BP}$, date suggests very rapid advance of initial Trafalgar ice, which reached points near its outer margin at roughly the same time.

\section{Christensen Bog series}

Site in Hancock Co, $9.6 \mathrm{~km} \mathrm{~N}$ of Greenfield $\left(39^{\circ} 52^{\prime} 00^{\prime \prime} \mathrm{N}, 85^{\circ} 49^{\prime}\right.$ $30^{\prime \prime} \mathrm{W}$ ). Coll 1977 and subm by $\mathrm{R}$ W Graham, Indiana Univ-Purdue Univ, Indianapolis.

ISGS-501.

$12,060 \pm 100$

From upper part of shell zone, $32.5 \mathrm{~cm}$ from surface datum. Comment (RWG): date is min for mastodon horizon.

ISGS-610. Soil 1

$13,070 \pm 90$

Bog soil from 80 to $90 \mathrm{~cm}$ below surface datum in shell zone.

ISGS-492.

$13,220 \pm 100$

Wood from organic bog sediments containing mollusks and vertebrates, $94 \mathrm{~cm}$ below datum. Comment (RWG): dates lower half of shell zone; with date of upper part of shell zone (ISGS-501), indicates fossiliferous deposits accumulated in slightly more than $1000 \mathrm{yr}$ but probably less than $1500 \mathrm{yr}$.

ISGS-505.

$13,360 \pm 100$

Wood from lacustrine sediments, $100 \mathrm{~cm}$ below datum, just below contact with shell zone.

ISGS-504.

$13,820 \pm 80$

From lacustrine deposits, $115 \mathrm{~cm}$ below datum. 
ISGS-502.

$14,080 \pm 150$

From lacustrine deposits, $125 \mathrm{~cm}$ below datum. Comment (RWG): date agrees with dates from outwash below (ISGS-491) and shell zone above (ISGS-492 and -501) and establishes correlation between strata from $\mathrm{N}$ and $\mathrm{S}$ ends of excavation.

ISGS-491.

$14,550 \pm 80$

Wood from glacial outwash deposits $40 \mathrm{~cm}$ thick, below lacustrine sediments and above till. Comment (RWG): date is max for formation of Christensen Bog and dates outwash sediments to last glaciation of central Indiana.

\section{Brazil, Indiana series}

Site in Clay Co, $3.8 \mathrm{~km}$ SE of Brazil $\left(39^{\circ} 30^{\prime} \mathrm{N}, 87^{\circ} 04^{\prime} \mathrm{W}\right)$. Coll 1977 by R V Ruhe and C G Olson; subm by R V Ruhe.

ISGS-523.

$25,480 \pm 420$

Insoluble humin fraction from Alb horizon of Farmdale Soil.

ISGS-524.

$23,690 \pm 980$

Humic acids extracted from ISGS-523.

General Comment (RVR): agreement of humin and humic acid dates precludes significant contamination by "younger" carbon.

\section{ISGS-541. Fillmore Section $\quad 20,660 \pm 180$}

Coniferous wood from Putnam Co, $4.2 \mathrm{~km} \mathrm{~N}$ of school in Fillmore $\left(39^{\circ} 42^{\prime} 30^{\prime \prime} \mathrm{N}, 85^{\circ} 45^{\prime} \mathrm{W}\right)$, from basal $15 \mathrm{~cm}$ of calcareous Wisconsinan till in stream cut at junction of Miller and Clear Creeks. Coll 1977 by C G Olson, M C Moore, and R V Ruhe; subm by R V Ruhe. Comment (RVR): date correlates well with ISGS-475: 20,110 $\pm 360 \mathrm{BP}$, and helps determine correlation of tills in $\mathrm{N}$ Indiana to loess in SW part of state.

\section{Northwest Rockville series}

Organic silt from Parke Co, $4 \mathrm{~km} \mathrm{NW}$ of Rockville $\left(47^{\circ} 30^{\prime} 08^{\prime \prime} \mathrm{N}\right.$, $\left.87^{\circ} 16^{\prime} 08^{\prime \prime} \mathrm{W}\right)$. Coll 1978 and subm by N K Bleuer.

ISGS-567. 7.3 to $7.45 \mathrm{~m}$ depth $22,080 \pm 220$

From upper organic zone. Comment (NKB): date most probably is of shear-sliced equivalent of lower silt in same hole (ISGS-568).

ISGS-568. 15.2 to $15.5 \mathrm{~m}$ depth

$22,960 \pm 200$

From lower organic zone. Comment (NKB): date is max for Lake Michigan Lobe Wisconsinan margin.

\section{West-Central Indiana series}

Samples from auger holes. Coll 1978 and subm by N K Bleuer.

ISGS-582. 30-14-8

$20,990 \pm 160$

Organic silt from Parke Co, $4.5 \mathrm{~m}$ WNW of Rosedale $\left(39^{\circ} 38^{\prime} 15^{\prime \prime} \mathrm{N}\right.$, $87^{\circ} 20^{\prime} 00^{\prime \prime} \mathrm{W}$ ), from gray to black silt zone, 7.6 to $7.8 \mathrm{~m}$ below surface. 
Comment (NKB): dates Lake Michigan Lobe Wisconsinan margin near SE-most extent (16km S of ISGS-567 and -568).

ISGS-583. Parke Co, 29-14-8

$24,790 \pm 230$

Mucky silt from Parke Co, $3.5 \mathrm{~km}$ WNW of Rosedale $\left(39^{\circ} 38^{\prime} 15^{\prime \prime} \mathrm{N}\right.$, $87^{\circ} 20^{\prime} 00^{\prime \prime} \mathrm{W}$ ), from mucky black clay zone, 2.7 to $2.9 \mathrm{~m}$ below surface. Comment (NKB): date is max for loess and extraglacial flow deposition just beyond Lake Michigan Lobe Wisconsinan margin. Indicates poorly drained bog condition several thousand yr before main Wisconsinan advance.

\section{ISGS-598. Park Co}

$25,480 \pm 400$

Organic silt from Park Co, $6 \mathrm{~km}$ WNW of Rosedale $\left(39^{\circ} 37^{\prime} 45^{\prime \prime} \mathrm{N}\right.$, $87^{\circ} 21^{\prime} 06^{\prime \prime} \mathrm{W}$ ), from organic silt zone, 3.05 to $3.35 \mathrm{~m}$ below surface. Comment (NKB): date is anomalously old, older than date of base of underlying unit, ISGS-582: 20,990 \pm 160 BP. Conceivably, unit is old organic material derived from dirty surface of ice margin.

ISGS-597. Vigo Co

$21,580 \pm 180$

Woody silt from Vigo Co, $2 \mathrm{~km} \mathrm{~W}$ of W Terre Haute $\left(39^{\circ} 30^{\prime} 10^{\prime \prime} \mathrm{N}\right.$, $87^{\circ} 30^{\prime} 30^{\prime \prime} \mathrm{W}$ ), from silt zone assoc with wood fragments, 8.53 to $8.69 \mathrm{~m}$ below surface. Comment (NKB): date is max for Lake Michigan Lobe advance of Wedron Formation, and verifies W-668 date nearby, and ISGS-582 to NE in Parke Co.

\section{Vanderburgh Co series}

Fibrous organic material from Vanderburgh Co. Coll 1979 and subm by G S Fraser, Indiana Geol Survey.

ISGS-617.

$\mathbf{3 9 8 0} \pm \mathbf{8 0}$

Sample from $8.3 \mathrm{~km} \mathrm{SSW}$ of Evansville ( $37^{\circ} 52^{\prime} 55^{\prime \prime} \mathrm{N}, 87^{\circ} 38^{\prime} 20^{\prime \prime} \mathrm{W}$ ), from organic zone near base of Ohio $\mathrm{R}$ alluvium. Comment (GSF): sample was taken near scarp of "Cary" Terrace. Date suggests that nearly all of this extensive flood plain accumulated in a very short time.

ISGS-640.

$2140 \pm 100$

$\delta^{1 s} C=-28.6 \%$

Sample from $12.5 \mathrm{~km} \mathrm{SSW}$ of Evansville $\left(37^{\circ} 50^{\prime} 30^{\prime \prime} \mathrm{N}, 87^{\circ} 38^{\prime} 20^{\prime \prime}\right.$ $\mathrm{W})$, from organic zone near base of alluvium similar to deposits of overbank material from modern Ohio R. Comment (GSF): sample was taken near middle of Holocene flood plain. Coupled with ISGS-617, date suggests that meander loop prograded at constant rate since it began to form.

\section{Battaglia Bog series}

\section{F. Ohio}

Site in Portage Co, $2.4 \mathrm{~km} \mathrm{SE}$ of Kent. Coll 1973 by L C Shane and Alan Black; subm by L C Shane, Kent State Univ. 
ISGS-249.

$$
10,060 \pm 160
$$

Sphagnum from filled kettle hole at core depth 209 to $214 \mathrm{~cm}$, Pollen Zone II (Shane, 1972). Comment (LCS): dates initiation of Pinus max. Age ca 500 yr younger than expected; other dates from NE United States place shift "away" from Pinus dominance to Quercus dominance at ca 10,000 BP (Ogden, 1967).

ISGS-250.

$13,640 \pm 210$

Gyttja from core depth 350 to $360 \mathrm{~cm}$, coorelates with top of pollen Zone I-A (Shane, 1972). Comment (LCS): agrees with ISGS-249 and is also slightly younger than expected.

ISGS-252.

$15,570 \pm 340$

Gyttja mixed with marl from core depth 466 to $486 \mathrm{~cm}$, near base of Pollen Zone I-A (Shane, 1972). Comment (LCS): since basin deposition does not usually begin for 1000 to $3000 \mathrm{yr}$ after ice retreat (Mickelson and Borns, 1972; Shane, 1972) and there are ca 25 to $35 \mathrm{~cm}$ more of marly gyttja below sample and above sand base, date supports concept that interlobate area is several thousand yr older than most of late Wisconsinan glaciated Ohio and is consistent with predicted basal date of 17,000 to $19,000 \mathrm{BP}$. This estimated basal date is min for retreat of Kent ice from Portage Co, Ohio.

\section{Quillin Brother Gravel Pit series}

Site in Medina Co, $3.9 \mathrm{~km} \mathrm{SE}$ of Lodi Square $\left(41^{\circ} 00^{\prime} 39^{\prime \prime} \mathrm{N}, 81^{\circ} 58^{\prime}\right.$ $38^{\prime \prime}$ W). Coll 1975 and 1978 by S M Totten and G W White; subm by G W White, Univ Illinois.

ISGS-348.

$14,050 \pm 80$

Wood from base of organic sand and silt unit, $2.4 \mathrm{~m}$ thick, overlying gravel and sand, and underlying peat. Comment (GWW): dates first appearance of vegetation after retreat of Hiram (late Woodfordian) ice from area, $7.1 \mathrm{~km} \mathrm{~N}$ of Hiram boundary.

ISGS-618.

$9320 \pm 90$

Peat from large block of flattened dense peat that slid several $\mathrm{ft}$ from main peat face. Comment (SMT): agrees well with ISGS-410: 8150 \pm 120 BP from in situ peat layer, and with ISGS-409: 10,470 \pm 100 from gyttja directly beneath peat. Date determines age of vole skull and sparrow (?) skeleton.

\section{Quillin Site series}

Site in Medina Co, $4.8 \mathrm{~km} \mathrm{SE}$ of Lodi $\left(41^{\circ} 00^{\prime} 37^{\prime \prime} \mathrm{N}, 81^{\circ} 58^{\prime} 35^{\prime \prime} \mathrm{W}\right)$. Coll 1975 by L C Shane and T L Kinch; subm by L C Shane.

ISGS-411.

$4690 \pm 100$

Peat from 0.3 to $0.4 \mathrm{~m}$ below top of deposit.

ISGS-410.

$8150 \pm 120$

Peat from 0.9 tolm. 
ISGS-658.

Peat from cut face $1.32 \mathrm{~m}$ below defined surface.

ISGS-407.
$8790 \pm 180$

$\delta^{13} C=-26.8 \%$

Small Abies log from $2 \mathrm{~m}$ depth, assoc with Populus and Salix wood; $0.5 \mathrm{~m}$ below pine needle layer. Comment (LCS): dates "pine max" pollen zone.

ISGS-409.

$10,470 \pm 100$

Matrix gyttja from $2 \mathrm{~m}$ depth. Comment (LCS): material directly surrounding Abies sample (ISGS-407). Similarity of dates rules out biologically incorporated Paleozoic carbon at this level.

ISGS-621.

$12,550 \pm 230$

$\delta^{1 s} C=-26.1 \%$

Wood fragments from cut face $3.25 \mathrm{~m}$ below defined surface. Below this level, pollen is generally $>50 \%$ spruce, whereas below, spruce drops to ca $20 \%$ and ironwood and oak increase. Date correlates well with other dates for this shift in W Ohio.

ISGS-622.

$12,470 \pm 140$

Wood fragments from cut face $4.47 \mathrm{~m}$ below defined surface.

ISGS-403.

$12,260 \pm 90$

Picea $\log$ from $5.08 \mathrm{~m}$ depth.

ISGS-405.

$13,400 \pm 140$

Gyttja from near basal deposit at depth 5.6m.

ISGS-402.

$14,500 \pm 150$

Organic material mixed with lake clay from dark "litter layer" at contact between glacial sand and basal lake sediments Comment (LCS): date represents minimal ice-free date for area unless "litter" zone was formed on top of melting ice block (Florin and Wright, 1969).

ISGS-432. Rock Fork

Wood from Franklin Co, $2 \mathrm{~km} \mathrm{E}$ of Gahanna $\left(40^{\circ} 01^{\prime} 05^{\prime \prime} \mathrm{N}, 82^{\circ} 51^{\prime}\right.$ $05^{\prime \prime}$ W), from coarse boulder gravel at base of Lockbourne Formation. Coll 1972 and subm by R P Goldthwait, Ohio State Univ.

ISGS-433. Executive Estates

$42,220 \pm 850$

Wood chips from Licking Co, $4.7 \mathrm{~km}$ SSW of Etna $\left(39^{\circ} 55^{\prime} 00^{\prime \prime} \mathrm{N}\right.$, $82^{\circ} 41^{\prime} 41^{\prime \prime} \mathrm{W}$ ), from drill hole $62 \mathrm{~m}$ deep to just above shale bed rock. Coll 1973 by J R Snavely and M J Quinn; subm by R P Goldthwait.

\section{ISGS-437. Avon-North Ridge Gravel Pit}

$13,050 \pm 100$

Wood from Lorain Co, Ohio, $0.3 \mathrm{~km}$ E of Sheffield $\left(41^{\circ} 25^{\prime} 33^{\prime \prime} \mathrm{N}\right.$, $82^{\circ} 03^{\prime} 52^{\prime \prime} \mathrm{W}$ ), from organic layer over sand and gray till, overlain by sand and gravel. Coll 1976 and subm by S M Totten, Hanover Coll, 
Hanover, Indiana. Comment (SMT): site is shoreline of earliest Lake Warren I in Erie Basin. Date agrees well with interpretation of Warren I originating soon after Arkona III, dated to 13,600 \pm 500 .

ISGS-590. Somers Farm North

Wood from Preble Co, $3.1 \mathrm{~km} \mathrm{~N}$ of Fairhaven $\left(39^{\circ} 37^{\prime} 40^{\prime \prime} \mathrm{N}, 84^{\circ} 45^{\prime}\right.$ $50^{\prime \prime}$ W), from 1.68m above base of Whitewater Till. Coll 1978 and subm by D P Stewart, Miami Univ, Oxford, Ohio. Comment (DPS): date confirms correlation of till with Whitewater and terminus of Whitewater in region.

ISGS-604. Doty's Highbank

$21,070 \pm 100$

Wood from Butler Co, $4 \mathrm{~km}$ N of Oxford $\left(85^{\circ} 43^{\prime} 55^{\prime \prime} \mathrm{N}, 39^{\circ} 33^{\prime} 05^{\prime \prime}\right.$

$\mathrm{W})$, from contact between units that were allegedly New Paris Interstadial deposits (below) and Middle Wisconsinan till (above). Coll 1978 and subm by D P Stewart. Comment (DPS): date proves that whole sec at Doty's Highbank $(22.9 \mathrm{~m})$ is Late Wisconsinan. Former dates on "Stump Zone", 6.1m above, are incorrect.

\section{ISGS-639. Alden Lower Pit}

$(128.9 \pm 1.2) \%$ modern

Wood from Summit Co, 2km WNW of Cuyahoga Falls $\left(41^{\circ} 08^{\prime} 32^{\prime \prime}\right.$ $\mathrm{N}, 81^{\circ} 32^{\prime} 28^{\prime \prime} \mathrm{W}$ ), from gray leached clayey silt, 1.5 to $2.25 \mathrm{~m}$ below surface. Coll 1978 and subm by J P Szabo, Univ Akron, Ohio. Comment (JPS): date implies severe erosion of slopes in Mud Brook drainage. Human activity on upper slopes freed much sediment for transport to lower slopes, where it is deposited as gully fill or alluvial fans.

\section{Arlington Canyon, Santa Rosa Island series}

Site in Santa Barbara Co, 60km WSW of Santa Barbara $\left(33^{\circ} 59^{\prime} \mathrm{N}\right.$, $\left.120^{\circ} 09^{\prime} \mathrm{W}\right)$. Coll 1978 and subm by D L Johnson, Univ Illinois.

ISGS-602.

$1890 \pm 80$

Buried organic soil. Comment (DLJ): date indicates that alluviation in Arlington Canyon ceased at some point later than 1885 BP, followed by entrenchment and stream-downcutting of alluvial fill.

ISGS-609.

$(99.3 \pm 0.1) \%$ modern

Wood from $2.1 \mathrm{~m}$ below surface of alluvial fill. Comment (DLJ): because ISGS-602 overlies this sample and is older, it is most probably rootwood of shrub that grew on surface of sec within historic time.

ISGS-580.

$10,800 \pm 80$

Wood from peaty muck ( 8.1 to $8.9 \mathrm{~m}$ below alluvial fill surface) that outcrops along floor of canyon intermittently along $0.25 \mathrm{~km}$. Comment (DLJ): wood id. by R C Koeppen as "Pinus, of yellow pine group" most probably Pinus torreyana, which is still present as relict stand on this island. 
ISGS-543.

$11,330 \pm 150$

Charcoal from peaty muck outcrop occurring on floor of canyon. Comment (DLJ): date complements ISGS-580 obtained on wood (Pinus), and indicates that coniferous elements and fires were present on this part of Santa Rosa Island during period 11,300 to 10,800 BP.

ISGS-542. Tecolote Canyon, Santa Rosa Island

$34,550 \pm 490$

Charcoal from Santa Barbara Co, $60 \mathrm{~km}$ WSW of Santa Barbara $\left(33^{\circ} 59^{\prime} 39^{\prime \prime} \mathrm{N}, 120^{\circ} 10^{\prime} 23^{\prime \prime} \mathrm{W}\right)$. From lower concave upward interface of classic "fire area." Coll 1978 and subm by D L Johnson. Comment (DLJ): red, highly oxidized "fire area" contains exposed fused rock rendered to pumicelike character, which reflects intense heat. Feature has no apparent anthropic implications, and may have been formed by burning roots of wind-or age-toppled tree; soil and stones adhering to roots wøuld have been oxidized and fused.

\section{Christy Alluvium, Santa Cruz Island series}

Site in Santa Barbara Co, $40 \mathrm{~km}$ SW of Santa Barbara $\left(34^{\circ} 01^{\prime} \mathrm{N}\right.$, $\left.119^{\circ} 52^{\prime} \mathrm{W}\right)$. Coll 1978 and subm by D L Johnson.

ISGS-544.

$$
4840 \pm 80
$$

Abalone shell from midden, $1.6 \mathrm{~m}$ below surface of alluvial terrace. Comment (DLJ): date is consistent with stratigraphy and insular archaeology.

ISGS-578.

$43,200 \pm 1100$

"Fire area" from in situ growth position at lower interface of area and subjacent alluvium. Comment (DLJ): greater than expected age of "fire area" sheds new light on age of this part of Christy Alluvium. Abundance of "fire areas" in alluvium suggests that many trees were growing on ancient alluvial flats during Wisconsinan stage of Pleistocene. "Fire areas" probably represent forest fires where wind-thrown and age-toppled trees, and soil adhering to their upthrown roots were burned and oxidized.

\section{Running Springs, San Miguel Island series}

Site in Santa Barbara Co, 56km WSW of Santa Barbara $\left(34^{\circ} 02^{\prime} 44^{\prime \prime}\right.$ $\left.\mathrm{N}, 122^{\circ} 25^{\prime} 34^{\prime \prime} \mathrm{W}\right)$. Coll 1978 by D L Johnson and M L Barnhardt; subm by $\mathrm{D} \mathrm{L}$ Johnson.

ISGS-518.

$16,520 \pm 150$

Charcoal from buried colluvial soil, $1.7 \mathrm{~m}$ below surface, in direct assoc with burned and calcined pygmy mammoth bones.

ISGS-525.

$15,630 \pm 460$

Same sample as ISGS-518, but charcoal briefly leached with cold $0.1 \mathrm{~N} \mathrm{NaOH}$.

General Comment (DLJ): dates indicate that both mammoth and cypress were living on island at ca $16,000 \mathrm{BP}$. 
Mollusk shells from Harding Co, $1.6 \mathrm{~km} \mathrm{~N}$ of Gallegos (35 $36^{\prime} 45^{\prime \prime}$ $\left.\mathrm{N}, 103^{\circ} 44^{\prime} 15^{\prime \prime} \mathrm{W}\right)$, from $3 \mathrm{~m}$ above creek channel and $4.6 \mathrm{~m}$ below top of terrace in basin fill. Coll 1974 by J C Frye and A B Leonard; subm by J C Frye. Comment (JCF): dates molluscan fauna and basin fill, now dissected by Ute Creek. Extensive terrace level is at top of basin deposits. Date is consistent with terrace date upstream in tributary (ISGS-347), but is older than terrace date $40 \mathrm{~km}$ upstream along Ute Creek (ISGS-373).

\section{ISGS-344. Miera Section}

$27,500 \pm 1300$

Unionid shells from Union Co, $29 \mathrm{~km}$ SE of Pasamonte $\left(36^{\circ} 05^{\prime} 20^{\prime \prime}\right.$ $\mathrm{N}, 103^{\circ} 31^{\prime} 15^{\prime \prime} \mathrm{W}$ ), from Wisconsinan terrace deposit of tributary to Canadian R. Coll 1974 by J C Frye and A B Leonard; subm by H D Glass, ISGS. Comment (JCF): dates major terrace with abundant molluscan fauna of Tramperos Creek. Contrasts strongly with age of terraces of comparable height in Ute Creek drainage; this drainage enters Canadian R ca $120 \mathrm{~km}$ downstream from mouth of Ute Creek, and has a lower gradient than Ute Creek.

\section{ISGS-346. MeCarty Ranch SW Section}

$21,180 \pm 560$

Gastropod shells from Harding Co, $24.5 \mathrm{~km}$ NNW of Logan $\left(35^{\circ} 31^{\prime}\right.$ $15^{\prime \prime} \mathrm{N}, 103^{\circ} 29^{\prime} 45^{\prime \prime} \mathrm{W}$ ), from fossiliferous sand and silt unit, 0.3 to $0.8 \mathrm{~m}$ thick, within sequence of lake beds. Coll 1973 by J C Frye and A B Leonard; subm by H D Glass. Comment (JCF): dates fauna and deposits in large undrained basin fill below Kansan surface $\mathbf{N}$ of Logan. Area adjacent to basin is ca $61 \mathrm{~m}$ below Ogallala Formation upland to $\mathrm{N}$.

\section{ISGS-347. Tequesquite Creek Section}

$8860 \pm 230$

Organic silt from Harding Co, $18.5 \mathrm{~km}$ SSW of Bueveros $\left(35^{\circ} 49^{\prime} 30^{\prime \prime}\right.$ $\mathrm{N}, 103^{\circ} 45^{\prime} 40^{\prime \prime} \mathrm{W}$ ), from lens of organic silt, $1.5 \mathrm{~m}$ above creek bed and 3m below terrace surface. Coll 1974 by J C Frye and A B Leonard; subm by $\mathrm{H}$ D Glass. Comment (JCF): dates extensive low terrace and molluscan fauna along Tequesquite Creek. This valley joins that of Ute Creek NW of Logan, New Mexico. Date agrees with those of two samples on Ute Creek, above (ISGS-373), and below (ISGS-343) mouth of Tequesquite Creek. Ute Creek is tributary to Canadian R, W of Logan; dates also indicate young age of low terrace of Canadian $\mathrm{R}$.

\section{Cimmaron Valley series}

Site in Union Co, $13 \mathrm{~km} \mathrm{NE}$ of Folsom $\left(36^{\circ} 55^{\prime} 30^{\prime \prime} \mathrm{N}, 103^{\circ} 43^{\prime} 50^{\prime \prime}\right.$ W). Coll 1975 by J C Frye and H D Glass; subm by J C Frye.

ISGS-369.

Clam shells from above basalt flow at base of Cimmaron $\mathrm{R}$ Valley, 0.6 to $1.2 \mathrm{~m}$ below top of young terrace. Comment (JCF): dates lowest terrace deposits and molluscan fauna in Cimmaron R Valley. 
ISGS-389.

$1690 \pm 100$

Charcoal mixed with silt and sand from fire pit in middle of very young terrace, above basalt. Comment (JCF): date indicates basalt flow is older than $1690 \mathrm{BP}$ and Indian habitation of valley $\mathrm{E}$ of Folsom lasted much later than at Folsom sites.

ISGS-370.

$840 \pm 80$

Clam shells from Union Co, $18.5 \mathrm{~km}$ NNE of Guy $\left(36^{\circ} 57^{\prime} 36^{\prime \prime} \mathrm{N}\right.$, $103^{\circ} 21^{\prime} 44^{\prime \prime} \mathrm{W}$ ), from main terrace of Cimmaron R Valley. Comment (JCF): dates younger terrace of Cimmaron R Valley in NE New Mexico. Date compares with date from comparable terrace deposit (ISGS-369), $48 \mathrm{~km}$ upstream to $\mathrm{W}$ and demonstrates young age of incision of Cimmaron R Valley.

\section{ISGS-372. Trementina Creek}

$1650 \pm 80$

Clam shells from San Miguel Co, $1.5 \mathrm{~km}$ NNW of Trementina $\left(35^{\circ}\right.$ $28^{\prime} 46^{\prime \prime} \mathrm{N}, 104^{\circ} 25^{\prime} 54^{\prime \prime} \mathrm{W}$ ). From $0.9 \mathrm{~m}$ below top of terrace, $1.8 \mathrm{~m}$ high, of Trementina Creek. Coll 1975 by A B Leonard and J C Frye; subm by J C Frye. Comment (JCF): dates minor young terrace and molluscan fauna of Trementina Creek, tributary to Conchos $\mathrm{R}$, which enters Canadian $\mathrm{R}$ a few $\mathrm{km}$ downstream. Along with dates from Tequesquite Creek and Ute Creek, confirms young active incision of Canadian $R$ system.

\section{ISGS-373. S Bueyeros}

Clam shells from Harding Co, $3 \mathrm{~km}$ SSW Wof Bueyeros $\left(35^{\circ} 58^{\prime} 23^{\prime \prime}\right.$ $\mathrm{N}, 103^{\circ} 41^{\prime} 36^{\prime \prime} \mathrm{W}$ ), from lower part of terrace of Ute Creek, ca $4.5 \mathrm{~m}$ high. Coll 1975 by A B Leonard and J C Frye; subm by J C Frye. Comment (JCF): dates youngest terrace and molluscan fauna of Ute Creek. Major terrace ca 40km downstream was dated as older (ISGS-343), and terrace dated here is probably equivalent in age to minor (undated) floodplain terrace downstream.

\section{ISGS-458. Yeso North Site}

$20,500 \pm 600$

Gastropod shells from De Baca Co, $4.8 \mathrm{~km}$ of Yeso $\left(34^{\circ} 28^{\prime} 01^{\prime \prime} \mathrm{N}\right.$, $104^{\circ} 34^{\prime} 41^{\prime \prime} \mathrm{W}$ ), from fossiliferous sand at apparent periphery of saline basin on surface of Ogallala Fm. Coll 1975 by A B Leonard and J C Frye; subm by A B Leonard, Univ Kansa, Lawrence. Comment (ABL): gastropod shells represent sp characteristic of cooler and more humid climate that occurred 15,000 to 20,000 BP in New Mexico.

\section{ISGS-607. Pecos Crossing \\ $5200 \pm 150$}

Unionid shell fragments from Eddy Co, $2.4 \mathrm{~km} \mathrm{SE}$ of Malaga $\left(32^{\circ} 10^{\prime}\right.$ $20^{\prime \prime} \mathrm{N}, 104^{\circ} 05^{\prime} \mathrm{W}$ ), from sandy silt terrace of Late Pleistocene (Wisconsinan). Coll 1978 by A B Leonard and J C Frye; subm by A B Leonard. Comment (ABL): date agrees with other dates from 6 to $8 \mathrm{~m}$ terrace deposited by Pecos $\mathrm{R}$ below abandoned Portales drainage, and provides important information on study of Pleistocene history of Pecos $R$ in New Mexico. 


\section{Hagerman North series}

Site in Chaves Co, $3.2 \mathrm{~km} \mathrm{~N}$ of Hagerman $\left(33^{\circ} 08^{\prime} 30^{\prime \prime} \mathrm{N}, 104^{\circ} 30^{\prime}\right.$

W). Coll 1978 by A B Leonard and J C Frye; subm by A B Leonard.

ISGS-585.

$400 \pm 100$

Carbon from hearth in exposure of sandy terrace above Rio Felix, tributary to Peco R, $30.5 \mathrm{~cm}$ below present surface.

\section{ISGS-608.}

$6390 \pm 120$

Unionid shells from exposed vertical face of terrace above Rio Felix, 1.83 to $2.44 \mathrm{~m}$ below present surface. Date agrees with other dates from 6 to $8 \mathrm{~m}$ terrace on Pecos $\mathrm{R}$ below abandoned Portales drainage.

\section{ISGS-615. Las Vegas East}

$1300 \pm 80$

Sphaeriid clam shell from San Miguel Co, $3.2 \mathrm{~km} \mathrm{E} \mathrm{of} \mathrm{Jct} \mathrm{US} \mathrm{Hwy}$

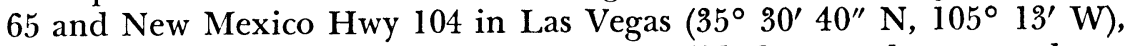
from yellowish clayey silt containing Sphaeriid clams and gastropods on terrace, $18.3 \mathrm{~m}$ alt, $180 \mathrm{~m}$ from Gallinas R. Coll 1978 by A B Leonard and J C Frye; subm by A B Leonard. Comment (ABL): date is only clue to age of Gallinas $\mathrm{R}$ in vicinity of Las Vegas, New Mexico.

\section{Other Localities}

\section{Matanuska Glacier series, Alaska}

Wood from Matanuska-Susitna Borough, $147 \mathrm{~km}$ ENE of Anchorage $\left(62^{\circ} 47^{\prime} 08^{\prime \prime} \mathrm{N}, 147^{\circ} 45^{\prime} 05^{\prime \prime} \mathrm{W}\right)$. Coll 1974 and subm by D E Lawson, Univ Illinois.

ISGS-296.

$$
520 \pm 80
$$

From basal ice of Matanuska Glacier, $4 \mathrm{~m}$ below present ice surface, $0.5 \mathrm{~m}$ below boundary between basal ice and white ice, and $1 \mathrm{~m}$ above sediment cover.

\section{ISGS-312.}

$$
\mathbf{3 5 0} \pm \mathbf{8 0}
$$

From basal ice zone of glacier, $1.1 \mathrm{~m}$ below present ice surface and $0.5 \mathrm{~m}$ above sediment cover.

General Comment (DEL): dates incorporation of materials in basal ice after ca 600 BP. Although exact age of overlying white ice is unknown, it is estimated as much older (perhaps 1000 to $2000 \mathrm{BP}$ ). Thus, dates imply materials were incorporated into base of ice sheet rather than from surface in accumulation zone.

\footnotetext{
ISGS-327. Spencer Glacier, Alaska $\quad(163.4 \pm 0.4) \%$ modern

Wood from ice cave, $17 \mathrm{~km} \mathrm{~S}$ of Anchorage $\left(60^{\circ} 41^{\prime} 00^{\prime \prime} \mathrm{N}, 149^{\circ} 00^{\prime}\right.$ $45^{\prime \prime} \mathrm{W}$ ), from white ice, $38.9 \mathrm{~m}$ from surface, $2.1 \mathrm{~m}$ above ice-bedrock interface and $2 \mathrm{~m}$ above floor of cave. Coll 1974 and subm by D E Lawson. Comment (DEL): dates incorporation into ice sheet to modern times, but method of incorporation cannot be determined. Wood may have fallen into crevasse near ice margin or was carried into basal portions of glacier by supra- and englacial streams.
} 
ISGS-612. Greenwood E Section, Mississippi

$19,310 \pm 460$

Shell from Carroll Co, $12 \mathrm{~km} \mathrm{E}$ of Greenwood $\left(33^{\circ} 30^{\prime} 06^{\prime \prime} \mathrm{N}, 90^{\circ} 02^{\prime}\right.$

$28^{\prime \prime} \mathrm{W}$ ). From interval of Peoria Loess, $1.5 \mathrm{~m}$ thick, $1 \mathrm{~m}$ above base. Coll 1978 by J C Frye and H B Willman; subm by H B Willman. Comment (HBW): date is comparable to dates from this strat position elsewhere in Illinois, and indicates no significant change in age of Peoria Loess down Mississippi Valley.

ISGS-613. Yazoo City, Mississippi

$18,400 \pm 400$

Shell from Yazoo Co, 5km SE of Yazoo City $\left(32^{\circ} 17^{\prime} 55^{\prime \prime} \mathrm{N}, 90^{\circ} 22^{\prime}\right.$ $26^{\prime \prime} \mathrm{W}$ ), from calcareous zone in lower part of Peoria Loess. Coll 1978 by J C Frye and H B Willman; subm by H B Willman. Comment (HBW): date is comparable to dates of shells from approx same strat position in Upper Mississippi Valley.

ISGS-326. Old Field, Advance Lowland, Missouri $\quad \mathbf{8 8 1 0} \pm 90$

Peat from Stoddard Co, $7 \mathrm{~km} \mathrm{E}$ of Advance $\left(37^{\circ} 06^{\prime} 14^{\prime \prime} \mathrm{N}, 89^{\circ} 04^{\prime}\right.$ $31^{\prime \prime} \mathrm{W}$ ), from base of peat deposit, $2.3 \mathrm{~m}$ thick, which covers ca $8 \mathrm{~km}^{2}$ in closed basin. Coll 1974 by J E King and W H Allen, Jr; subm by J E King. Comment (JEK): dates beginning of peat development in large swamp in Mississippi R Valley and min age of last river occupation of $\mathrm{W}$ side of its valley.

\section{Porter Gap Section series, Tennessee}

Site in Lauderdale Co, $10.5 \mathrm{~km}$ WNW of Halls $\left(35^{\circ} 52^{\prime} 30^{\prime \prime} \mathrm{N}, 89^{\circ}\right.$ $\left.30^{\prime} 00^{\prime \prime} \mathrm{W}\right)$. Coll 1979 by E D McKay, J A Lineback, and H B Willman; subm by E D McKay.

\section{ISGS-652.}

$23,390 \pm 200$

Wood (conifer) from upper $0.2 \mathrm{~m}$ of silty muck, $1.4 \mathrm{~m}$ thick, that extends from 0.5 to $1.9 \mathrm{~m}$ above base of section of Peoria Loess, 7 to $9 \mathrm{~m}$ thick, at top of E bluff of Mississippi Valley. Comment (EDM): date approximates occurrence of change in valley train composition from higher to lower dolomite, transition from loess zone P-2 to P-3 (McKay, 1979a; $1979 \mathrm{~b}$ ), and agrees with dates of same horizon in Peoria Loess of SW Illinois (ISGS-307, -413).

\section{ISGS-653.}

$24,990 \pm 270$

Wood in muck from lower $0.1 \mathrm{~m}$ of same muck bed dated by ISGS652. Comment (EDM): date is approx for base of Peoria Loess at this locality and agrees well with basal Peoria dates from several sites along Mississippi and Illinois Valleys in Illinois.

ISGS-656.

$\delta^{13} \mathrm{C}=-26.0 \%$

Wood in muck from upper $0.2 \mathrm{~m}$ of Farmdale Soil in Robein Silt. Comment (EDM): date is approx for burial of Farmdalian landscape adjacent to Mississippi Valley by first increments of Peoria Loess derived from valley following mid-Wisconsinan (Farmdalian) ice retreat. Agrees with date of Farmdale Soil in its type region. 


\section{Spear Lake Bog series, Wyoming}

Organic silt from Johnson Co, $39.4 \mathrm{~km}$ WNW of Bussalo $\left(44^{\circ} 25^{\prime} 26^{\prime \prime}\right.$ $\left.\mathrm{N}, 107^{\circ} 11^{\prime} 15^{\prime \prime} \mathrm{W}\right)$. Coll 1977 and subm by M L Barnhardt, Illinois State Univ, Normal, from bog below two hanging cirques, one of which contains three well-defined moraines and sufficient evidence to suggest additional fourth advance. Oldest moraine possesses moderately welldeveloped soil and is probably of very late Pinedale (Pinedale IV) age; other moraines are Neoglacial.

$$
\begin{array}{llr}
\text { ISGS-515. } & 106 \text { to } 136 \mathrm{~cm} \text { depth } & 8000 \pm 110 \\
\text { ISGS-514. } & 136 \text { to } 166 \mathrm{~cm} \text { depth } & 7000 \pm 140 \\
\text { ISGS-520. } & 121 \text { to } 166 \mathrm{~cm} \text { depth } & 4960 \pm 80 \\
\text { ISGS-513. } & 200 \mathrm{~cm} \text { depth } & 8200 \pm 80
\end{array}
$$

From basal unit of bog overlying bedrock ca $200 \mathrm{~cm}$ below surface. General Comment (MLB): dates period after which glacial ice was restricted to long, hanging cirques in which two and possibly three episodes of Neoglacial ice advance are recorded by moraines, rock glaciers, and pro-talus ramparts.

\section{Gladstone Lobe series, Canada}

Peat from Yukon Terr $\left(61^{\circ} 01^{\prime} 10^{\prime \prime} \mathrm{N}, 138^{\circ} 20^{\prime} 00^{\prime \prime} \mathrm{W}\right)$. Coll 1972 by C S Alexander and L W Price; subm by C S Alexander, Univ Illinois.

ISGS-442.

$$
900 \pm 100
$$

Peat from basal organic layer $3 \mathrm{~m}$ from front of solifluction lobe, ca $15 \mathrm{~cm}$ below top of permaforst.

ISGS-441.

$$
1480 \pm 80
$$

Peat from basal organic layer $7 \mathrm{~m}$ from front of solifluction lobe, ca $35 \mathrm{~cm}$ below top of permafrost.

\section{ISGS-435.}

$$
1620 \pm 80
$$

Peat from basal organic layer $10 \mathrm{~m}$ from front of solifluction lobe, ca $30 \mathrm{~cm}$ below top of permafrost.

\section{ISGS-443.}

$1800 \pm 100$

Peat from basal organic layer $11 \mathrm{~m}$ from front of solifluction lobe, ca $35 \mathrm{~cm}$ below top of permafrost.

ISGS-436.

$$
2100 \pm 80
$$

Peat from upper organic layer $8 \mathrm{~m}$ from front of solifluction lobe, just above permafrost.

General Comment (CSA): dates and field evidence suggest that lobe moved along at least two shear planes at differential rate, moving faster along basal plane. 


\section{REFERENCES}

Black, R F, 1976, Quaternary geology of Wisconsin and contiguous Upper Michigan, in Mahancy W C, ed, Quaternary stratigraphy of North America: New York, Halsted Press, p 93-117.

Bleuer, N K and Moore, M C, 1971, Glacial stratigraphy, buried landforms and early drainage at Fort Wayne, Indiana: Abs, Geol Soc America, N-central sec mtg, De Kalb, Illinois, v 4, p 309-310.

1972, Glacial stratigraphy of the Fort Wayne area and the draining of Glacial Lake Mawnee: Indiana Acad Sci Proc, 1971, v 81, p 195-209.

Coleman, D D, 1973, Illinois State Geological Survey radiocarbon dates IV: Radiocarbon, v 15, p $75-85$.

1974, Illinois State Geological Survey radiocarbon dates V: Radiocarbon, v 16, p $105-117$.

Ekblaw, G E and Willman, H B, 1955, Drift near Danville, Illinois: Illinois Acad Sci Trans, v 47, p 129-138.

Florin, $\mathrm{M}$ and Wright, H E, Jr, 1969, Diatom evidence for the persistence of stagnant glacial ice in Minnesota: Geol Soc America, Bull 80, p 695.

Follmer, L R, McKay, E D, Lineback, J A, and Gross, D L, 1979, Wisconsinan, Sangamonian and Illinoian stratigraphy in central Illinois: Midwest friends of the Pleistocene field conf, 26th, Illinois State Geol Survey, Guidebook 13, p 1-68.

Frye, J C, Glass, H D, and Willman, H B, 1962, Stratigraphy and mineralogy of the Wisconsinan Loesses of Illinois: Illinois State Geol Survey, Circ 334, 55 p.

1968, Mineral zonation of Woodfordian Loesses of Illinois: Illinois State Geol Survey, Circ 427, 44 p.

Frye, J C, Leanard, A B, Willman, H B, and Glass, H D, 1972, Geology and paleontology of Late Pleistocene Lake Saline, southeastern Illinois: Illinois State Geol Survey, Circ 471, 44 p.

Johnson, W H, Follmer, L R, Gross, D L, and Jacob, A M, 1972, Pleistocene stratigraphy of east-central Illinois: Illinois State Geol Survey, Guidebook 9, $97 \mathrm{p}$.

Kothandaraman, V, Evans, R L, Bhowmik, N G, Stall, J B, Gross, D L, Lineback, J A, and Dreher, G B, 1977, Fox Chain of Lakes investigation and water quality management plan: Illinois Water Survey-Illinois State Geol Survey, Cooperative Resources, rept $5,200 \mathrm{p}$.

McKay, E D, 1979a, Stratigraphy of Wisconsinan and older loesses in southwestern Illinois: 43rd ann tri-state geol conf, Illinois State Geol Survey, Guidebook 14, p 37-67. cene field conf, 26th, Illinois State Geol Survey, Guidcbook 13, p 95-108.

Mickelson, D M and Borns, H W, 1972, Chronology of a kettle-hole peat bog, Cherryfield, Maine: Geol Soc America, Bull 83, p 827-831.

Moore, M C and Bleuer, N K, 1972, An exposure of pre-Wisconsinan drift near Fort Wayne, Indiana: Abs, Indiana Acad Sci Proc, 1972, v 82, p 265-266.

Ogden, J G, III, 1967, Radiocarbon and pollen evidence for a sudden change in climate in the Great Lakes region approximately 10,000 years ago, in Cushing, E J and Wright, H E, ed, Quaternary paleoecology: New Haven, Yale Univ Press, p 117-127.

Risatti, B J, ms, 1977, Geochemical and microbial aspects of Volo Bog, Lake County, Illinois: $\mathrm{Ph} \mathrm{D}$ dissert, Univ Illinois.

Ruhe, R V, 1969, Quaternary landscapes in Iowa: Ames, Iowa, Iowa State Univ Press, $255 \mathrm{p}$.

Shane, L, ms, 1972, A pollen sequence from a bog in the interlobate area, Portage County, Ohio: MS thesis, Kent State Univ.

Wayne, W J, 1963, Pleistocene formations in Indiana: Indiana Geol Survey, Bull 25, $85 \mathrm{p}$. Geol Survey, Progress rept 28, 15 p.

White, G W, 1968, Age and correlation of Pleistocene deposits at Garfield Heights, Cleveland, Ohio: Geol Soc America, Bull 79, p 749-752.

Willman, H B and Frye, J C, 1970, Pleistocene stratigraphy in Illinois: Illinois State Geol Survey, Bull 94, 204 p. 